\title{
The Political Competition-Economic Performance Puzzle: Evidence from the OECD Countries and the Italian Regions
}

\author{
FABIO PADOVANO \\ ROBERTO RICCIUTI
}

CESIFO WORKING PAPER NO. 2411

CATEgORY 5: Fiscal POLICY, MACROECONOMICS AND GROWTH

SEPTEMBER 2008

\footnotetext{
An electronic version of the paper may be downloaded

- from the SSRN website:

- from the RePEc website:

www.SSRN.com

www.RePEc.org

- from the CESifo website:

www.CESifo-group.org/wp
} 


\title{
The Political Competition-Economic Performance Puzzle: Evidence from the OECD Countries and the Italian Regions
}

\begin{abstract}
Empirical tests of the theories on the relationship between political competition and economic performance generate a puzzle: data tend to support the theory at the lower levels of government, but not in panels of countries. We argue that the larger set of policy instruments reduces the tax price of votes at the national level, increasing the incentives to use distortionary redistributive policies to win contested elections. Moreover, constitutions reserve competencies with a high ideological potential to the national government, reducing swing voters' responsiveness to the economic performance of the central government. We thus expect political competition to produce efficiency-oriented policies at the sub-national level compared to the national one. We test this hypothesis on a panel of 24 OECD countries over 1974-2000 and a panel of 15 Italian regions over 1984-2000 and find support for our predictions.
\end{abstract}

JEL Code: D78, H71, H72, O17.

Keywords: political competition, growth, redistribution, national and regional government.

Fabio Padovano

Dipartimento di Istituzioni

Pubbliche, Economia e Società

University of Rome 3

Via G. Chiabrera 199

00145 Rome

Italy

padovano@uniroma3.it
Roberto Ricciuti

Dipartimento di Studi sullo Stato

University of Florence

Via delle Pandette 21

50127 Florence

Italy

roberto.ricciuti@unifi.it

Paper presented at the 23rd European Economic Association Conference (Milan), the 2008 European Public Choice Conference (Jena), the 2007 PEARLE seminar of the University of Tampere and 19th Scientific Meeting of the Italian Society of Public Economics. We wish to thank Stefano Bartolini, Massimo Bordignon, Emma Galli, Antti Moisio, Yvon Rocaboy, Annalisa Vinella and all participants to the seminar for their helpful comments. The usual caveat applies. 


\section{Introduction}

Since Marshall's Principles of Economics, economists have been trained to believe that market competition maximizes the welfare of the consumers, while monopoly and market power create economic rents for the benefit of producers. First public choice, then political economics attempted to import this notion into the analysis of political market, often using economic performance as a benchmark to evaluate the welfare properties of the alternative equilibria. Such 'implant' turned out to be a difficult one, because once one looks below the surface of the analogies between market structures and equilibria, a host of differences distinguish political markets from economic ones. Political markets reach their equilibrium through voting and several other processes, not just exchange; they are characterized by a large variety of institutional constraints, they produce a multiplicity of policy decisions, not a single commodity, the time profile of their processes is more complex; and the list could be made longer.

The most recent theoretical formulations of this idea mark a significant advance in the solution of the first problem, as they use the probabilistic voting model to describe the political market and exploit the idea that stiffer political competition leads to the selection of politicians better able at resisting interest groups pressures to obtain transfers financed by distortionary taxation. Such ability is interpreted as a measure of the 'quality' of politicians; similarly, the degree of distortion of private choices defines the quality of the policy decisions. The solution to the second problem comes from the consideration that economies are constituted by different sectors with different levels of productivity. Since the highgrowth, it can be said that more competitive sectors are the most likely victims of distortionary policies, political competition enhances economic efficiency and liberates resources for income growth.

The empirical testing of this argument, however, provides ambiguous results. The main predictions of the theory generally find support at the level of sub-national governments; but at the level of national governments, where the most important policy decisions are taken, the data seem to contradict the theory.

The tasks of this paper are to refine the models of the literature so to provide a theoretical explanation of this puzzle, and to evaluate the merits of our explanation on empirical grounds. Specifically, our argument is that political competition alone is insufficient to promote the selection of more efficiency-oriented policies. Institutional constraints are also needed to secure an effective restriction of the politicians' choice set that excludes low-quality policies, resulting in poor economic performance. These constraints are generally tighter at the subnational government level, insofar as constitutions generally allow sub-national government politicians to decide upon a smaller set of policy issues, with lower ideological potential. These two factors limit the discretionary power and enhance political competition at the subnational government level relatively to the national one and explain why political competition yields more efficiency oriented policy choices at the sub-national level than at the national one.

The predictions of the model are then tested on two data sets, one about national political markets (the OECD countries), and the other about sub-national ones (the Italian Regions). A crucial feature of this theoretical literature is to consider political competition as a long-run, structural phenomenon, affected by structural events (e.g., institutional reforms), characterized by considerable durability, rather than as the outcome of day-to-day policy struggles or electoral contests. The strategy of empirical testing then revolves around the identification of an event that produces a permanent change in the competitiveness of the political market. Within the sample of the OECD countries the Fall of the Berlin Wall is the natural candidate for such an event, insofar as it permanently reduced the "ideological divide" in many countries, thereby expanding the political spectrum of parties that could compete for 
government positions. The choice of the Italian Regions is in turn motivated by the far reaching institutional reforms of 1995, which transformed the government system of the Regions from a parliamentary to a presidential one where voters can in fact directly select their governor. These reforms are widely believed to have enhanced the competitiveness (and accountability) of Italian regional politics. They represent an appropriate testing ground for the political competition-economic performance nexus at the sub-national level.

The rest of the paper is organized as follows. In section 2 we review the literature. Section 3 presents the theoretical model. Section 4 describes the empirical analysis on the sample of OECD national governments, while section 5 does the same for the Italian Regions. Section 6 reassumes the main results of the analysis, compares them with the rest of the literature and points out avenues for future research.

\section{Literature review}

Early public choice analyses of the link between political competition and economic performance, such as Downs (1957) and Becker (1958), set the argument for the study below. Competition among political parties or candidates for office maximizes voters' welfare inasmuch as it reduces political rents, e.g., the tax price at which government services are supplied, and works as an information revealing-mechanism that improves the efficiency of the principal-agent relationship between voters and elected representatives. The literature that developed these early contributions focused on imperfections of the political market, through notions such as rational ignorance, efficiency losses of representation, voting and decision making procedures, bundling in political decisions, problems of time inconsistency in politicians' incentives, as well as how alternative institutional frameworks affect the efficiency properties of political market equilibria. However, all these inquiries shared the paradigmatic conviction that more political competition enhances citizens' welfare (Wittman, 1989, 1995; Stigler, 1972; Barro, 1973). Even when severe inefficiencies taint the electoral processes and institutions, competition among interest groups shares many of the welfare properties of market competition (McCormick and Tollison, 1981; Becker, 1983). To further strengthen the argument, political economics models have shown that lopsided political competition engenders welfare losses, due to excessive rent seeking (Polo, 1998) and inefficiencies in the provision of government services (Svensson, 1998).

At the same time, the macroeconomic literature on economic growth examined the link between political competition and economic efficiency from the opposite point of view, namely, whether greater degrees of economic efficiency, usually measured by higher income levels or growth rates, are correlated with more democratic governments (Barro, 1996; Barro and Sala-i-Martin, 2004). The underlying assumption is that democratic regimes are associated with political competition, while dictatorial ones can be taken as the analogue of a monopolistic political market. The predictions are ambiguous: on the one hand, greater political competition is usually correlated with more economic freedom, lower constraints on the efficient allocation of resources and accumulation of knowledge, which leads to faster growth. On the other hand, dictatorships are believed to redistribute less, to be better able to control rent-seeking, and to face a lower risk of wars of attrition than democracies - all factors that should induce a better economic performance, ceteris paribus. Empirical findings suggest a combined, nonlinear effect of democracy and freedom on growth. Increases in democracy raises growth at low levels of political freedom but lowers growth when moderate levels of freedom have been attained. Przeworski et al. (2000) find no statistical difference in growth performance between the two regimes, probably because it is questionable that dictatorships redistribute less than democracies (Wintrobe, 1998) and because the economic structure under dictatorships shows considerable variations, spanning market-oriented Chile under Pinochet 
to the planned economy of the former Soviet Union. All in all, the empirical analyses support the greater competition-greater efficiency hypothesis only in part (Wintrobe, 2007). ${ }^{1}$

More recently, a series of theoretical formulations, such as Krusell and Rios-Rull (1996), Persson and Tabellini (2000), Besley, Persson and Sturm (2006) and Besley and Preston (2007) have collapsed the various arguments on the relationship between political competition and economic efficiency into a single model. In particular, Besley et al. (2006) summarize the argument as follows. Individuals usually base their voting decisions on an economic dimension, related to the performance of the economy during the government tenure. In some cases, however, they consider an ideological dimension too, based on a non-economic and resilient issues such as race, religion, nation and the like. When ideology is relevant, it blunts voters' responsiveness to economic issues and gives a disproportionate electoral advantage (a political rent) to one party. ${ }^{2}$ This lack of accountability allows the party that enjoys the political rent to select low-quality politicians as candidates for political offices, and special interest groups, antithetical to growth, to capture the political process. The economic consequences are policy choices targeted at redistribution rather than efficiency and income growth. Besley et al. (2006) test the predictions of the model on data about the U.S. States. They exploit the "Right to Vote" laws of 1965-1970s as an exogenous shock that destroyed the political rent enjoyed by the Democratic Party in the Southern States since the end of the Civil War, and which contributed to the ensuing growth take-off of the American South. They find strong empirical support for the hypothesis that tighter political competition produces higher State income levels and growth rates, lower tax pressure, more business friendly regulation and a higher quality of Governors.

The model is at the same time comprehensive and rigorous. Furthermore, the empirical support it receives within the U.S. States sample is so impressive that it has already stimulated an empirical literature aimed at verifying the generality of the findings. This literature lends only mixed support to the predictions of the theories on the relationship between political competition and economic performance. Ashworth et al. (2006) examine the competitionefficiency nexus in a sample of Flemish municipalities. They find that political competition does have a beneficial effect on the efficiency of municipality performance; these effects, however, are in part mitigated in that stiffer competition may lead to more fragmentation in governments that works against efficiency. Besley and Preston (2007) verify that mayors of English municipalities where redistricting measures have destroyed a political rent moderate their policy choices. A variation of this theory meets support also in the context of Indian village policies (Besley et al., 2007). However, moving up the ladder of government level, things seem to change. In a panel of OECD countries, Padovano and Ricciuti (2007) fail to find empirical support for the predictions of Besley et al. (2006) for what it concerns both economic performance and fiscal policy. Contrary to the evidence related to lower levels of government, greater political competition at the national level seems to produce worse economic performance and less efficient fiscal policies. When political rents are dissipated and offices are tightly contested, national politicians appear to resort to redistributive, rather than efficiency oriented policies in order to buy votes. This short run political strategy reduces long run economic efficiency.

All in all, these contrasted empirical analyses propose a puzzle whose solution requires a more refined theoretical model.

\footnotetext{
${ }^{1}$ Giavazzi and Tabellini (2005) look at a large panel of countries and find that the sequence of political and economic liberalization matter, as countries that first liberalize the economy and then become democracies do much better than countries that pursue the opposite sequence, in almost all dimensions.

${ }^{2}$ In the framework of this theoretical structure, a dictatorial government can be taken as one where only the ideological dimension matters and voting is ineffective as a selection mechanism.
} 


\section{The theoretical model}

In this section we provide a modified version of Besley et al. (2006) model to illustrate how political competition may affect policy choices and economic performance in different ways at different government levels, always through the same transmission mechanism, namely, the quality of politicians and the type of policy choices. Our innovation is concentrated on the differences between national and sub-national levels of government and on the way these differences affect fiscal policies and economic performances. We opt to present the whole theoretical structure here, to better show how our contribution fits into the general theoretical structure.

Political competition in any government level is characterized by two parties that select candidates for the elections of the President of the national government and of the subnational ones. Both national and sub-national elections are held according to the same institutional procedures. The population is composed by two groups of citizens, one that work in a traditional sector, the other that draw income only from a technologically advanced sector, $^{3}$ with no differences of composition between the various sub-national units. ${ }^{4}$ The elected President decides the policies and redistributes resources among the two sectors to maximize his/her political returns. Those who work in the traditional sector protect their quasi-rents by lobbying. They are more successful at capturing the government the more uneven is political competition, the lower is the 'quality' of the President and the greater is the set of policies that the President controls. The constitution divides the political competencies of the national and the sub-national governments, avoiding overlaps. This demarcation generates two sources (or channels) of differences between the two government levels in the impact of political competition on economic performance through two separate channels.

First the constitution assigns administrative tasks, with low ideological potential, to subnational governments and reserve political ones, with higher ideological potential (such as foreign policy or income redistribution), to the national government (Alesina and Tabellini, 2007; 2008). In the model this is captured by a parameter that determines two intercepts in the function relating political competition to economic performance, one the national government, the other for sub-national ones. Second, the constitution allows the national government to raise revenues through a higher number of tax instruments relative to those assigned to the sub-national ones, thereby reducing the incidence of each fiscal levy per equal amount of expenditures to be financed and, because the excess burden of taxation increases with the square of the effective tax rate, decreasing the overall distortions of private choices. National presidents have thus a lower cost of redistributing resources to buy votes than presidents of sub-national governments. The lower tax price of votes relaxes a binding constraint on the incentives of national politicians to fight contested elections by selecting more distorsive policies, thereby decreasing the efficiency enhancing properties of political competition at the national level relative to the sub-national ones. The model describes this difference by means of a coefficient on the redistributive costs of policy choices of national governments that takes different values according to the government level. As a result there

\footnotetext{
${ }^{3}$ In Besley et al (2006) the traditional sector is represented as agriculture and the modern one as a capital intensive activity, but as Krusell and Rios-Rull (1996) show, the logic of the argument is however applicable to any economy where a group of industries is less productive than another.

${ }^{4}$ If we allowed the subnational jurisdictions to differ in the shares of the technologically advanced and traditional sectors in their economies, we would add another dimension of redistribution, which would only reinforce the logic of the argument. Padovano (2007) provides such a model.
} 
will be two different slopes of the political competition-economic performance function for the two government levels.

Aside from these differences, the structure of the model is essentially the same as in Besley et al. (2006). Political competition improves economic performance only to the extent that it is not lopsided. The distortion consists in an electoral advantage of one party arising from a surplus of committed voters. This surplus is in turn generated by one party's advantage in representing a set of non-economic, resilient issues, called ideology, which can be thought of as race, religion, nation and the like. In a sub-national government context such as the American South race provides the ideological dimension; at the level of national government in many countries, before the fall of the Berlin Wall, the example could be an anti-Communist ideological stance. The degree of political competition increases as this ideological dimension, and the annexed electoral advantage, looses importance. When it exists, however, such electoral advantage reduces the dominant party's incentive to appeal to swing voters, who are not committed on ideological issues and are prepared to vote against candidates more interested to cater lobbies. Given the relatively lower price of votes, at the national level the incentives to appeal to swing voters to win the elections decrease more rapidly per equal increase of salience of the ideological, lobby-sensitive issue, thus making the national political market less prone to promote economic efficiency than the sub-national one. Furthermore, as sub-national governments decide upon less ideologically sensitive issues, voters interested in protecting their economic rents by lobbying will find it less costly to 'buy off' national politicians. Also for this reason, national politicians will be less pro economic growth than sub-national ones.

The timing of the model is the traditional one of probabilistic voting models. First, each party picks a candidate for President (for both government levels) under uncertainty about a popularity shock. Second, this shock is realized as voters vote. Third, whoever is elected President at both government levels receives transfers from vested interests and selects a set of policies. At the last stage, private economic choices are made, which yield economic outcomes conditioned by the policies chosen at each government level. The next three subsections deal with these choices in reverse order. Thus, we first describe the economic model, then the political model, and finally the full politico-economic equilibrium for both economic levels.

\subsection{The economic model}

Two sectors (traditional and advanced) and two periods characterize the economy. The key questions for the politics-economic nexus are how those who work in the traditional sector can protect their quasi-rents now and how such protection affects economic growth later. Within a finite population of size $M$, each citizen differs in their economic and political type. Political types are discussed in the next subsection. Economic types, denoted by $I \in\{K, L\}$ refer to the ownership of factors of production. One group, $I \equiv K$ has $(1-\alpha) M$ members, who work only in the "new" sector $N$. The other group, $I \equiv L$ with size $\alpha M$, works in the traditional sector $T$ and is endowed with the same amount of traditional factor of production $l, l / \alpha$. In period 1 every citizen has the same endowment, $y_{1}$, which can be consumed or invested in either of the two sectors $S \in\{T, N\}$. The period 1 budget constraint of an individual from group $I$ is thus $c_{1}^{I}+k^{I, T}+k^{I, N}=y_{1}$ where $c_{1}^{I}$ is his first-period consumption and $k^{I, T}$ and $k^{I, N}$ are his investments in the traditional and new sector, respectively. In period 2, the same consumption good can be produced with two different technologies, associated with the two different sectors of production. In the new sector, production requires only capital and takes place according to a linear technology $Y^{N}=M A k^{N}$, where $Y^{N}$ is output of the new sector and $k^{N}$ per capita investment in the new 
sector. The traditional sector instead has a well-behaved, constant-returns-to-scale production technology $Y^{T}=M Q\left(k^{T}, l\right)$, where $Y^{T}$ is output of the traditional sector, and $k^{T}$ per-capita investment in the traditional sector. $Q\left(k^{T}, l\right)$ is assumed to be increasing in both arguments with $Q_{k k}<0, Q_{l l}<0$ and $Q_{l k}>0$.

A citizen in group $I$ evaluates economic outcomes by the quasi-linear utility function $V^{I}=H\left(c_{1}^{I}\right)+c_{2}^{I}$ where $c_{j}^{I}$ is consumption in period $j$ and $H_{c}>0$, while $H_{c c}<0$. Relative profitability of capital in the two sectors will be affected by a host of different policies, including regulatory, industrial, labor market, and commercial policies, financed by an array of tax instruments $\tau_{j}$. These policies and associated tax instruments are exclusive competence of either the national or the sub-national government levels, and are thus decided exclusively by the respective President, with the President of the national government having more competencies (and, as we shall see later, more ideologically sensitive ones) than the subnational Presidents. A coefficient $\beta$, set at $\beta>1$ for the national government and at $\beta=1$ for the sub-national ones, captures the larger set of policy instruments that the constitution assigns to the national government. To simplify matters, we assume that there is no difference between the effective incidence of these different taxes $\tau_{j}$, i.e., the national President set them all at the same level $0 \leq \tau \leq 1$, and all on the output of the new sector. The per-capita tax proceeds $\beta \tau A k^{N}$ are distributed as an equal lump sum transfer $f$ to every individual in the economy. The period 2 budget constraint of an individual from group $I$ is thus $c_{2}^{I}=(1-\beta \tau) A k^{I, N}+Q_{k} k^{I, T}+Q_{l} l^{I}+f$ where $l^{I}$ denotes per-capita holdings of the traditional factor in group $I$; furthermore we have exploited that in equilibrium the reward to each factor equals its marginal product. Importantly, the period 2 budget constraint shows that, for any level of $f$, the national government can set taxes at a lower rate, due to the higher level of $\beta$. Per policy, this reduces the tax price of redistribution at the national level.

When savings and investments are chosen, the overall level of tax incidence $\beta \tau$ is already known, because economic choices are made after political ones. Optimal economic decisions imply that in (an interior) equilibrium:

$$
H_{c}\left(y_{1}-k^{I, T}-k^{I, N}\right)=A(1-\beta \tau)=Q_{k}\left(k^{T}, l\right) \text {. }
$$

The equilibrium condition shows that each person invests the same amount $k^{I}=k^{I, T}+k^{I, N}$, irrespective of whether he owns any amount of the traditional factor, and, since marginal rates of return are equal, individuals are indifferent between the two forms of investment. $^{5}$

Two are the key results of the economic model for the growth rate and the structure of the economy. First, the growth rate (of GDP and GDP per-capita):

$$
g(\beta \tau)=\frac{M\left(y_{2}-y_{1}\right)}{M y_{1}}=\frac{1}{y_{1}}\left[A\left(K(\beta \tau)-K^{T}(\beta \tau)\right)+Q\left(K^{T}(\beta \tau), l\right]-1\right.
$$

is a decreasing function of the tax pressure on the modern sector $\beta \tau$, since tax pressure depresses growth because it distorts the accumulation as well as the allocation of capital between the two sectors. Second, the share of the modern sector in period 2 output:

$$
s^{N}(\beta \tau)=\frac{A k^{N}}{y_{2}}=\frac{A\left(K(\beta \tau)-K^{T}(\beta \tau)\right)}{A\left(K(\beta \tau)-K^{T}(\beta \tau)\right)+Q\left(K^{T}(\beta \tau), l\right.}
$$

\footnotetext{
${ }^{5}$ See Appendix A for a characterization.
} 
is also a decreasing function of tax pressure on the modern sector. Because of the difficulties in identifying the less advanced productive sector in a panel of countries, in this paper we will test only the first prediction.

\subsection{The political model}

As mentioned above, each citizen has a political type $P$, defined by the utility obtained from non-economic issues. As in Persson and Tabellini (2001) we distinguish three types: Centre Left, Centre Right and Independents, $P=\in\{C L, C R, 0\}$. This characterization applies at both the national and sub-national political market. Partisan voters, who vote invariantly for one party, make up a share $1-\sigma$ of the population. Let $\delta(P, p) \Delta$ be the utility gain of a partisan from having his preferred political type, $p$, in the President office. Only the Centre Left and the Centre Right are organized in parties that select candidates for the office of Presidential of the national and sub national government(s), $p \in\{C L, C R\}$. Thus, we set $\delta(C L, C R)=\delta(C R, C L)=0$, and $\delta(P, P)=1$. As explained below, independents also care about the parties' stance on non-economic issues, but to a smaller degree than partisans.

The political model involves three types of players: 1) interest groups, 2) political parties and elected Presidents, and 3) voters.

1) Interest groups. Agents who benefit from the use of capital in the traditional sector become vested interests, as they have a stronger incentive to get organized in order to protect their quasi-rents. In sectors based on new technologies, where no such rents exist, interest groups are more costly to form. We thus assume that only the group $L$ (individuals belonging to the traditional sector) lobbies the elected President and his party, by paying a per member transfer $t$ in exchange of policy favors. To simplify the analysis, we assume that the group $L$ only consists of ideologically motivated citizens from both parties. As all members own the same amount of the traditional asset, we also assume that there is no policy conflict within the group. The utility level of the representative interest-group member, at the point of lobbying, is: $V^{P, L}(\beta \tau, t)=V^{L}(\beta \tau)-t=F(\beta \tau)+\frac{1-\alpha}{\alpha} R(\beta \tau) l-t$.

2) Parties and Elected Presidents. Each of the two parties, $C L$ and $C R$, comprises a small fraction of ideologically motivated citizens, with $P \in\{C L, C R\}$. Parties pick candidates for President of the national and sub-national governments among their members. After the election, the candidate elected President decides the level of overall policy incidence $\beta \tau$ (with $\beta=1$ at the sub-national government level) and decides how much transfers to take from the special interest. Elected candidates share any transfers they receive with party members, according to a fixed rule where the party's share is given by $\rho$ (where $\rho<1-1 / M$, to rule out trivial results). Party members differ in the amount of "shame" they attach to any bribe received. Let $q$, with $0 \leq q \leq 1$ denote the discounting due to shame, so a unit of transfers has value $1-q$ to a politician. As a higher shame reduces the value of a bribe, the parameter $q$ measures the "quality" of a candidate. The utility of the average party member when the policy is $\beta \tau$ and transfers are $t$ is: $V^{P}(\beta \tau, t)=V^{K}(\beta \tau)+\delta(P, p)\left(\Delta+\frac{\rho}{m}\left(1-q^{P}\right) t \alpha\right){ }^{6}$ Selecting a candidate for Presidential office thus amounts to picking a type $q_{p}$, which affects the level of $t$ if the election is won by party $P$.

$3)$ Voters. The two groups are defined by the political types above. A share $1-\sigma$ of the population, the types $P \in\{C L, C R\}$, strongly prefers one of the parties due to non economic

\footnotetext{
${ }^{6}$ For a derivation of this utility function see Appendix B.
} 
issues. We assume this preference to be strong enough that committed citizens vote for their preferred party no matter what; in the lexicon of the model, their utility gain $\Delta$ is large enough to dominate any economic concerns. Of these committed voters, a fraction $(1-\lambda) / 2$ prefers party $C L$. To fix ideas on the Italian sample, during the so-called First Republic we think about Catholic religion and anti-Communist ideology as the salient non-economic issue and the Christian Democrats (here the $C L$ party) as having an advantage among the committed voters in this dimension, i.e., $\lambda>0$. Other examples could be taken from France, Germany, Japan.

The remaining share $\sigma$ of voters are independent, type $P=0$, swing voters. Here the differences between the national and sub-national political markets become relevant, for two reasons. First, the assumption that all owners of the traditional asset are partisans implies that all swing voters are owners of the new asset. Thus, the economic payoff to a swing voter of having party $p \in\{C L, C R\}$ in office is $v_{p}=V^{K}\left(\beta \tau_{p}\right)$. This payoff increases with $\beta$ and decreases with $\tau_{p}$, since a higher number of policy decisions at the national level allow the President of the national government to reduce the incidence of each policy $\tau_{p}$ (and associated excess burden) to raise a given amount of resources compared to a President of a sub-national government that has to fulfill the same task. In addition, swing voters have an individual party preference, $\omega[\delta(0, C L)-\delta(0, C R)]$, for or against party $C L$ 's relative stance on non-economic issues, with $\omega \leq \geq 0$ distributed among the voters. A swing voter casts her ballot for party $C L$ whenever $\eta+\omega+v_{C L}-v_{C R}>0$ where $\eta$ is an aggregate popularity shock. If $G_{\omega}$ denotes the conditional density function for $\omega$, it is easy to show that party $C L$ wins when $\sigma\left[1-2 G_{\omega}\left(-\eta-v_{C L}\left(\beta \tau_{C L}\right)-v_{C R}\left(\beta \tau_{C R}\right)\right)\right]+(1-\sigma) \lambda>0$.

The $v_{C L}\left(\beta \tau_{C L}\right)-v_{C R}\left(\beta \tau_{C R}\right)$ in the previous equation reveals one channel through which political competition at national level can be distinguished from that at the sub-national level. To the extent that $\beta>1$, the national President can raise a given amount of revenues at a lower tax rate $\tau$, thereby resorting to less distorsive policies compared to the President of a sub-national government. This lowers the $v_{C L}\left(\beta \tau_{C L}\right)-v_{C R}\left(\beta \tau_{C R}\right)$ differential for swing voters at the national level than at the sub-national one, making them less sensitive to differences in economic performance delivered by the two parties at the national level. Hence swing voters will be less decisive in national elections. The national political market will thus be less prone to economic efficiency than the sub-national one. There a tax rise distorts private choices more and trigger a greater response of swing voters.

The support of the $\omega$ distribution conveys the relative salience of the ideological issue and the second dimension through which political competition at the national and sub-national government level differ. For the sake of simplicity, $\omega$ is assumed uniform on $\left[-\frac{\gamma}{2 \phi}, \frac{\gamma}{2 \phi}\right]$, where the parameter $\gamma$ indicates whether the issue is decided by the central government $(\gamma>1)$ at by the sub-national one $(\gamma=1)$. This parameterization captures the typical division of labor between government levels, whereby the national government deals with issues characterized by a higher ideological potential, while the sub-national governments are assigned administrative tasks with lower ideological potential. The parameter $\phi$, on the other hand, indicates the relative salience of non economic issues among swing voters, with a higher value of $\phi$ capturing lower salience. Finally, $\frac{\gamma}{2 \phi}<\Delta$; all swing voters have weaker preferences on non-economic issues than the partisan voters. We may use the support of the $\omega$ distribution to gauge the relative salience of non-economic issues among the swing voters. 
Under this parameterization, the condition for a Centre Left party win becomes $\sigma \frac{\phi}{\gamma}\left[\eta-v_{C L}\left(\beta \tau_{C L}\right)-v_{C R}\left(\beta \tau_{C R}\right)\right]+(1-\sigma) \lambda>0$, corresponding to the following critical value of the popularity $\hat{\eta}=\kappa-\left[v_{C L}\left(\beta \tau_{C L}\right)-v_{C R}\left(\beta \tau_{C R}\right)\right]$, where the composite parameter $\kappa=\frac{1-\sigma}{\sigma} \frac{\gamma \lambda}{\phi}$ is the key measure of (lack of) political competition. To further simplify the algebra, let $\eta$ be uniform on $\left[-\frac{1}{2 \xi}, \frac{1}{2 \xi}\right]$. We assume that parties pick their candidates for President knowing the distributions of $\omega$ and $\eta$, but not the realization of $\eta$. At that point in time, the probability of a Centre Left (the party with an ideological advantage) win is:

$$
P_{C L}\left(\kappa-v_{C L}-v_{C R}\right)=\left\{\begin{array}{c}
1 \text { if } \xi\left[\kappa+v_{C L}-v_{C R}\right] \geq \frac{1}{2} \\
\frac{1}{2}+\xi\left[\kappa+v_{C L}-v_{C R}\right] \\
0 \text { if } \xi\left[\kappa+v_{C L}-v_{C R}\right] \leq-\frac{1}{2}
\end{array}\right.
$$

Hence, this probabilistic voting model predicts the electoral success of the Centre Left to primarily depend on two conditions. One is the degree of political competition $\kappa$, with higher level of competition ( $\kappa$ closer to 0 ) reducing the probability of success of the Centre Left party. The other is the utility difference for swing voters resulting from the policies pursued by the Centre-Left and Centre-Right candidates, $v_{C L}\left(\beta \tau_{C L}\right)-v_{C R}\left(\beta \tau_{C R}\right)$. These conditions are in turn affected by the following factors:

1. As $\lambda$ falls, the Centre Left's advantage in terms of committed supporters decline;

2. As $\sigma$ becomes large, i.e., swing voters make up a larger fraction of the voting population and the Centre Left advantage declines;

3. As $\phi$ goes up, the salience of non-economic issues among the swing voters decreases and the Centre Left advantage declines;

4. As $\gamma$ increases (decisions are taken at the level of national government) the ideological potential of non-economic issues among the swing voters increases and the Centre Left advantage rises;

5. As $\beta$ rises, policy decisions are taken by the national government, where the tax price of redistributing resources is lower. The economic payoff to a swing voter of having a party or another diminishes and the Centre Left advantage rises.

Post election politics. The candidate and party winning the election is described by the pair $\left\{q_{p}, p\right\}$. In the post-election lobbying game, suppose the elected President can make a take-it-or-leave-it offer to the interest group. But the reservation utility of an interest group member cannot fall below the utility of the owner of a new asset (otherwise the interest group member would trade the traditional asset for the new one), so that $V^{K}(\beta \tau)=F(\beta \tau)-R(\beta \tau) l$. It follows from the utility level of the representative interest-group member that equilibrium transfers satisfy $t=\frac{R(\beta \tau) l}{\alpha}$. In other words, the rent from holding the traditional asset is fully captured and transferred to the President and his party. Since $R_{\tau}>0$, higher taxes go hand in hand with higher transfers.

The President's ex post payoff is $F(\beta \tau)+\Delta+R(\beta \tau) l+(1+\rho)\left(1-q_{p}\right) M-1$. Since there is no commitment in policy, the equilibrium tax rate is the ex post optimal tax rate for the elected President, i.e., $\tau\left(q_{p}\right)=\underset{\tau \in[0,1]}{\arg \max }\left\{F(\beta \tau)+\Delta+R(\beta \tau) l+(1+\rho)\left(1-q_{p}\right) M-1\right\}$. It is easy to show that $\beta \tau\left(q_{p}\right)$ is a declining function. Higher quality Presidents attach less value to transfers and are less prone to exchange money for policy favors to vested interests. 
Pre election politics. The main check on rent extraction by parties is the contest over swing-voter support. Effectively, parties compete by offering equilibrium utility levels of their candidates to the swing voters that are made 'incentive compatible' by picking Presidents who deliver such policies. The range of utility levels $[\underline{v}, \bar{v}]$ a party can credibly offer, however, depends on the range of possible Presidents.

We can now write the pre-election maximands of the Centre Left party:

$v_{C R}\left(\beta \tau_{C R}\right)+P_{C L}\left(\kappa+v_{C L}\left(\beta \tau_{C L}\right)-v_{C R}\left(\beta \tau_{C R}\right)\right)\left[\Delta+W\left(v_{C L}\left(\beta \tau_{C L}\right)\right)-v_{C R}\left(\beta \tau_{C R}\right)\right]$

and the Centre Right party:

$\Delta+W\left(v_{C R}\left(\beta \tau_{C R}\right)\right)-P_{C L}\left(\kappa+v_{C L}\left(\beta \tau_{C L}\right)-v_{C R}\left(\beta \tau_{C R}\right)\right)\left[\Delta+W\left(v_{C L}\left(\beta \tau_{C L}\right)\right)-v_{C R}\left(\beta \tau_{C R}\right)\right]$

where we have used that party members obtain the same utility as ordinary capitalists if their party does not gain office.

The trade-off facing parties should now be clear. Offering a higher utility to the swing voters - i.e., picking a higher quality Presidential candidate (someone with higher $q_{p}$ ) - they raise their chance of winning. This, however, reduces the rents they capture if winning $(\beta \tau$ and hence $t$ will be lower). This trade-off is stronger at the sub-national government level than at the national one, because a lower $\beta$ forces the President to set a higher $\tau$ at any level of $t$. An incumbent Centre-Left President of a sub-national government is therefore more constrained to use redistribution to secure his electoral advantage than his national counterpart. This makes the sub-national political market more prone to economic efficiency than the national one, a key prediction of our model.

The full politico-economic equilibrium reveals how this trade-off is resolved by party strategies. The only difference between the parties is captured by $\kappa$, which measures the extent of political competition. As we will see, because $\kappa>0$ the Centre Left (more generally, the party with an inherent electoral advantage) is less pro-growth. Intuitively, a party with a larger set of committed voters is tempted to pick politicians who care more about rents, protect the rents and the size of the traditional sector, and thereby retard growth. Again, because $\gamma>1$ is a directly related to the value of $\kappa$, the political rent is more resilient at the national level than at the sub-national one, and the ideological party will find it easier to implement growth retarding policies at the national level.

\section{Empirical analysis, OECD sample \\ 4.1. Empirical strategy}

The empirical verification of the model requires two key variables and two samples. The variables are an indicator of political competition $\kappa$ and a shock to it, which modifies the long run competitiveness of the political market. The two samples must refer one to national governments, the other to sub-national governments, and must allow the estimate of the same equations, to verify the hypothesized differences of the political competition-economic performance at the two government levels.

In this section we test the predictions of the model in a sample consisting of data drawn from 24 national governments of OECD countries, namely Australia, Austria, Belgium, Canada, Denmark, Finland, France, Germany, Greece, Iceland, Ireland, Italy, Japan, Mexico, Netherlands, New Zealand, Norway, Portugal, Spain, Sweden, Switzerland, Turkey, USA, and United Kingdom. The sample ensures a broad degree of homogeneity of economic conditions; furthermore, all these countries are democracies. Limitations in the data sources constrain the sample period to the 1974-2000 time interval.

The empirical literature that tests implications close to our model uses indicators of electoral bias as a measure of degree of political competition. Specifically, Besley et al. (2006) use the difference between the dominant party's electoral advantage relative to the mid-point of $50 \%$ of two-party vote support in their study of elections in the U.S. States. 
Ashworth et al. (2006) employ the margin between the first and the second largest party in their sample of Flemish municipalities. The first measure is more suitable in a two-party political system, but the countries and the regions in our samples typically include more than two parties and have a variety of government and electoral systems. We then resort to the margin between the first and the second largest party in parliamentary and/or presidential elections, according to the system. In majoritarian systems the two largest parties typically compete for the government, in proportional representation systems the two largest parties usually lead the coalitions that alternate in office. The source of this variable is the Database of Political Institutions (Beck et al, 2001). An alternative measure of the lack of political competition could have been the durability of government, based on the idea that a party with an ideological advantage enjoys a political rent which ensures a longer grip on government positions. This interpretation of such an indicator is ambiguous, as it would not distinguish the case of a government that performs well in a highly competitive political market and is reelected by voters. We have therefore opted for the margin between the two largest parties; yet, as we shall see below, we also use a battery of control variables to account for the effects of institutional differences on political competition as much as possible.

As we discuss in detail below, the theoretical literature reason in terms of long run structural events, not short run electoral outcomes because measures of political competition are not necessarily exogenous to the outcome variables that describe economic performance The usual strategy in this case is to construct instruments for political competition that are independent from the economic performance of the countries/states included in the sample. In the context of the OECD countries finding such an instrument is particularly difficult, as the usual ones employed for sub-national governments (institutional reforms, redistricting, extensions of the power to vote) become unavailable. What we need is an event that a) occurred in a definite moment of time; b) simultaneously affected the degree of competitiveness of the political markets of the OECD countries; c) is uncorrelated with the indicators of economic performance. As an instrument only the fall of the Berlin Wall and demise of Soviet Union meets all these requirements. These events reduced ideological polarization in countries with strong Communist Parties and increased political competition. According to our index, political competition in the 1974-1989 period was equal to 0.2577 , and in the period 1990-2000 was equal to 0.2655. Figure 1 shows the log of political competition in all countries of our sample before and after 1989.

Furthermore, this index does not appear to be positively correlated with per capita personal income, which would make it an unsuitable instrument: the relationship is negative in 18 cases, positive in 5, absent in 1. Figure 2 depicts the relationship between the index and per capita income for the overall sample, showing the lack of any correlation between the two variables. The institutional differences between countries may affect the degree of political competition: a $2 \%$ margin in a presidential system allows a much firmer position in government than in a parliamentary system; furthermore, two party competition is categorically different from competition among coalitions of parties. We have therefore considered a battery of control variables, including the degree of fractionalization of government coalitions, an indicator of whether the party/coalition supports the government has the majority in both Houses of the Parliament, a multivariate dummy that represents the government system (presidential, parliamentary or mixed), a dummy for the electoral system (majoritarian or proportional); finally, following La Porta et al. (1999) we have also considered the legal origins of the country (French, German, or UK). Table 1 gives the summary statistics of the variables involved in the analysis. 
Figure 1. Political competition before and after 1989

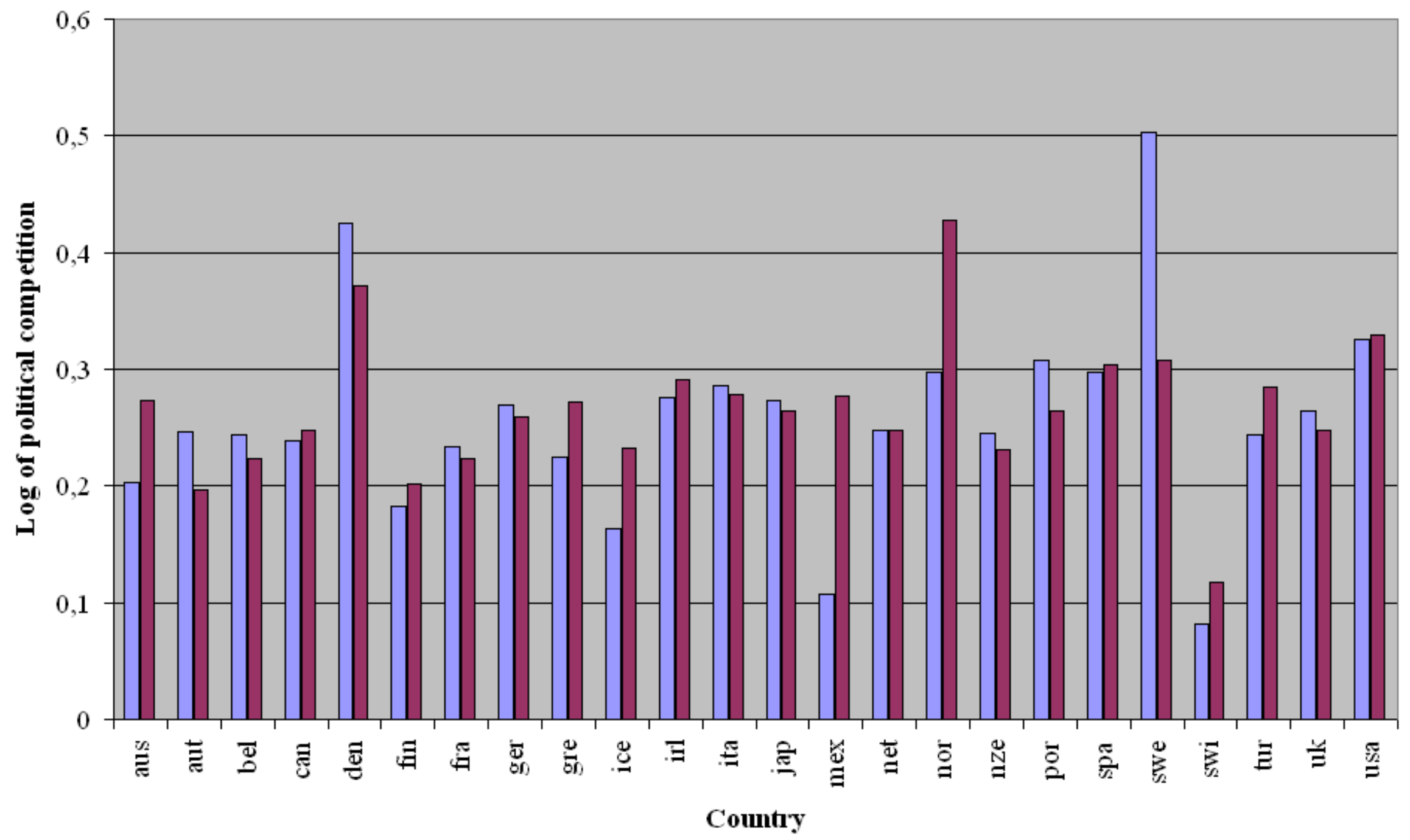


Figure 2. Political competition and economic growth

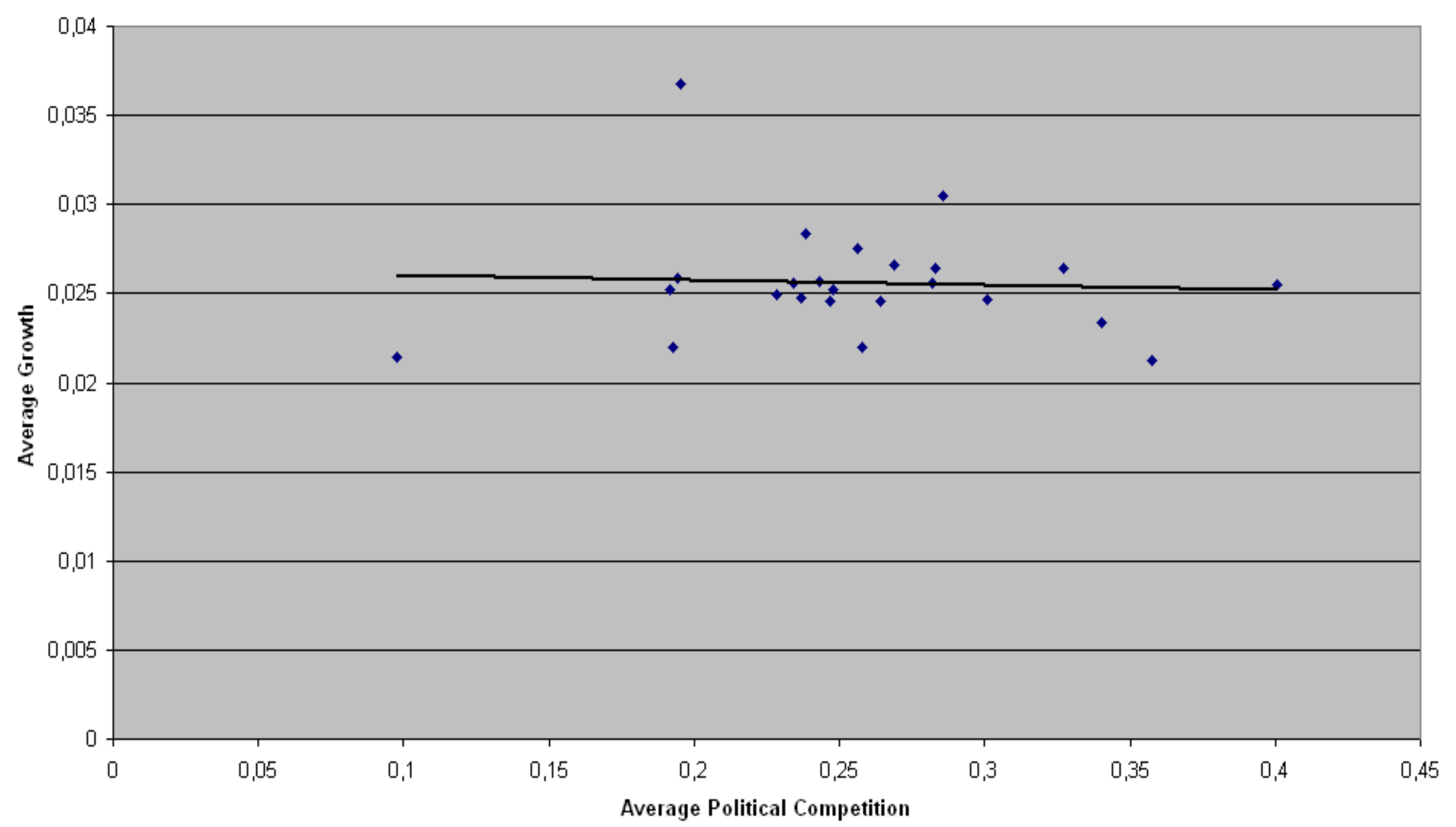


Table 1- Summary statistics, OECD sample

\begin{tabular}{|c|c|c|c|c|}
\hline & Mean & Std. Dev. & Min. & $\operatorname{Max}$ \\
\hline Per-capita income & 4.094 & 0.272 & 3.065 & 4.572 \\
\hline Growth rate & 1.917 & 2.618 & -9.753 & 10.748 \\
\hline$\kappa_{i t}$ (lack of political competition) & 0.258 & 0.095 & 0.000 & 0.951 \\
\hline Fractionalization & 0.673 & 0.119 & 0.000 & 0.897 \\
\hline Control of all Houses & 0.197 & 0.398 & 0.000 & 1.000 \\
\hline Majoritarian & 0.472 & 0.499 & 0.000 & 1.000 \\
\hline LegOr UK & 0.200 & 0.400 & 0.000 & 1.000 \\
\hline LegOr GER & 0.177 & 0.382 & 0.000 & 1.000 \\
\hline LegOr FRA & 0.399 & 0.489 & 0.000 & 1.000 \\
\hline Openness & 62.455 & 30.114 & 10.530 & 184.19 \\
\hline Investment(-1) & 24.289 & 4.8346 & 8.7286 & 42.167 \\
\hline Government spending & 17.232 & 4.0395 & 6.9093 & 27.950 \\
\hline Share of the Elderly & 12.516 & 3.341 & 3.710 & 18.071 \\
\hline (Lack of) Political comp. $1^{\text {st }}$ quintile & 0.0085 & 0.092 & 0.000 & 1.000 \\
\hline (Lack of) Political comp. $2^{\text {nd }}$ quintile & 0.131 & 0.338 & 0.000 & 1.000 \\
\hline (Lack of) Political comp. $3^{\text {rd }}$ quintile & 0.667 & 0.471 & 0.000 & 1.000 \\
\hline (Lack of) Political comp. $4^{\text {th }}$ quintile & 0.144 & 0.351 & 0.000 & 1.000 \\
\hline (Lack of) Political comp. $5^{\text {th }}$ quintile & 0.047 & 0.212 & 0.000 & 1.000 \\
\hline
\end{tabular}

\subsection{Income equation}

The baseline specification for estimating relationship between political competition and economic performance (model 1) is:

$$
y_{i t}=\alpha_{1} \kappa_{i t}+\alpha_{2} \mathbf{Z}_{i t}+\vartheta_{i}+\theta_{t}+\varepsilon_{i t}
$$

where $y_{i t}$ is personal income per capita of country $i$ in year $t ; \kappa_{i t}$ is measure of political competition, $\mathbf{Z}_{\mathrm{it}}$ is a vector of institutional controls, $\vartheta_{i}$ is country fixed effects and $\theta_{t}$ is a year dummy. The models are log linear. We use a battery of control variables to clean the estimates as much as possible: institutional and political differences, and legal systems.

In Table 2 we consider the relationship between political competition and the level of real personal income. When we simply regress lack of political competition on income (column 1) we find that the variable is insignificant. This result is not conclusive, because the coefficient $\alpha_{1}$ gives us the causal effect of political competition on $y_{i t}$ as long as $\kappa_{i t}$ is uncorrelated with $\varepsilon_{i t}$. In the context of our analysis, this condition may fail because of omitted factors influencing both economics and politics. In certain countries the Fall of the Berlin Wall may have destroyed pre-existing political rents and increased competition because the demise of the Soviet Union made voters feel that voting for a left-wing party no longer involved the risk of changing the set of national alliances. Furthermore, as already pointed out, it could also be the case that higher income stimulates political competition, thereby rising problems of reverse causation. To solve these potential problems, we resort to an IV strategy, using the year after the Fall of the Berlin Wall (1990) as our instrument. Specifically, Berlin is a dummy that takes the value of 0 from 1974 to 1989 and 1 afterwards. The IV strategy also addresses another possible bias in the estimate of $\alpha_{1}$. Our measure of political competition, the margin between the first and second major contestants in the elections, fluctuates temporarily from one election to the next. These short-run fluctuations will poorly approximate the comparative statics of $\kappa_{i t}$ in the model, which correspond to long-run changes in the degree 
of electoral competition. An IV strategy relying on an external shock to the competitiveness of the political markets of the OECD countries holds the additional advantage of removing the downward bias associated with such measurement error. Given the nature of the variables (lower margins indicate greater competition) this bias may be responsible for the 'wrong' sign obtained in OLS estimates. We thus consider a first-stage equation (model 2):

$$
\kappa_{i t}=c_{i}+d_{t}+\beta_{1} \text { Berlin }+\eta_{i t}
$$

where $c_{i}$ is a region fixed effect and $d_{t}$ a year fixed effect. Results from the IV version corresponding to (mod.1), using (mod.2) as the first stage, are found in column (2). The lack of political competition then becomes significant at the $1 \%$ level and positive. Significantly, this is in contrast with the rest of the literature, but consistently with what our model predicts for the national government level. In column 3 we add the legal origins of common law (UK) and continental law (France and Germany). Legal origins are credited to induce different degrees of competition and accountability in the economic systems, therefore affecting economic performance. Yet these variables do not change the sign of our measure of political competition. Our political competition measure is based on the distribution of seats. We then need to control for variables that affect how votes are transformed into seats. In columns 4 through 7 we consider three aspects that can affect political competition. In this analysis we are considering two-party and multi-party political systems, and accountability may be lower in the latter case, making it more difficult for voters to punish bad politicians. First, we introduce fractionalization, the probability that two legislators picked at random belong to different parties. In the war of attrition literature (Alesina and Drazen, 1991) this variable is negatively related with government responsiveness to adverse shocks to the economy. Second, we consider whether the coalition supporting the government control both Houses (if there is more than one Chamber). If the two Houses are controlled by different majorities, decisions may need further bargaining between political groups, and the fact that the government has the majority in only one Chamber may signal that the electoral race is extremely tied or that the distribution of seats leads to a head-to-head situation. Third, we introduce a dummy variable to control for a majoritarian voting rule, which determines a twoor three- party political environment with one party supporting the government, compared with the multi-party system of proportional representation that lead to coalitions supporting a government. ${ }^{7}$

Adding these variables does not modify the negative sign of the political competition variable. In columns 8 and 9 we address the issue of possible non-linearity in the relationship between political competition and income. In the former we add a variable that multiplies the lack of political competition with a dummy variable for the countries (France, Italy and Spain) in which their communist parties formed an alliance called Euro Communism. These parties were larger than in other countries and this might have affected political competition. There is a marginal effect on the size of the coefficient of the variable measuring the lack of political competition, but it still remains significantly positive at the $1 \%$ level. Finally, in column 9 we substitute the continuous measure of political competition with a dummy for each quintile. Only the quintile with the highest values of lack of political competition shows a negative and significant effect, whereas for the remaining for quintiles the effect is still positive.

\footnotetext{
${ }^{7}$ The multivariate dummy that represents the government system is never significant when considered with the above variables, and we do not report the estimates.
} 
Table 2 - Political competition and income, OECD countries.

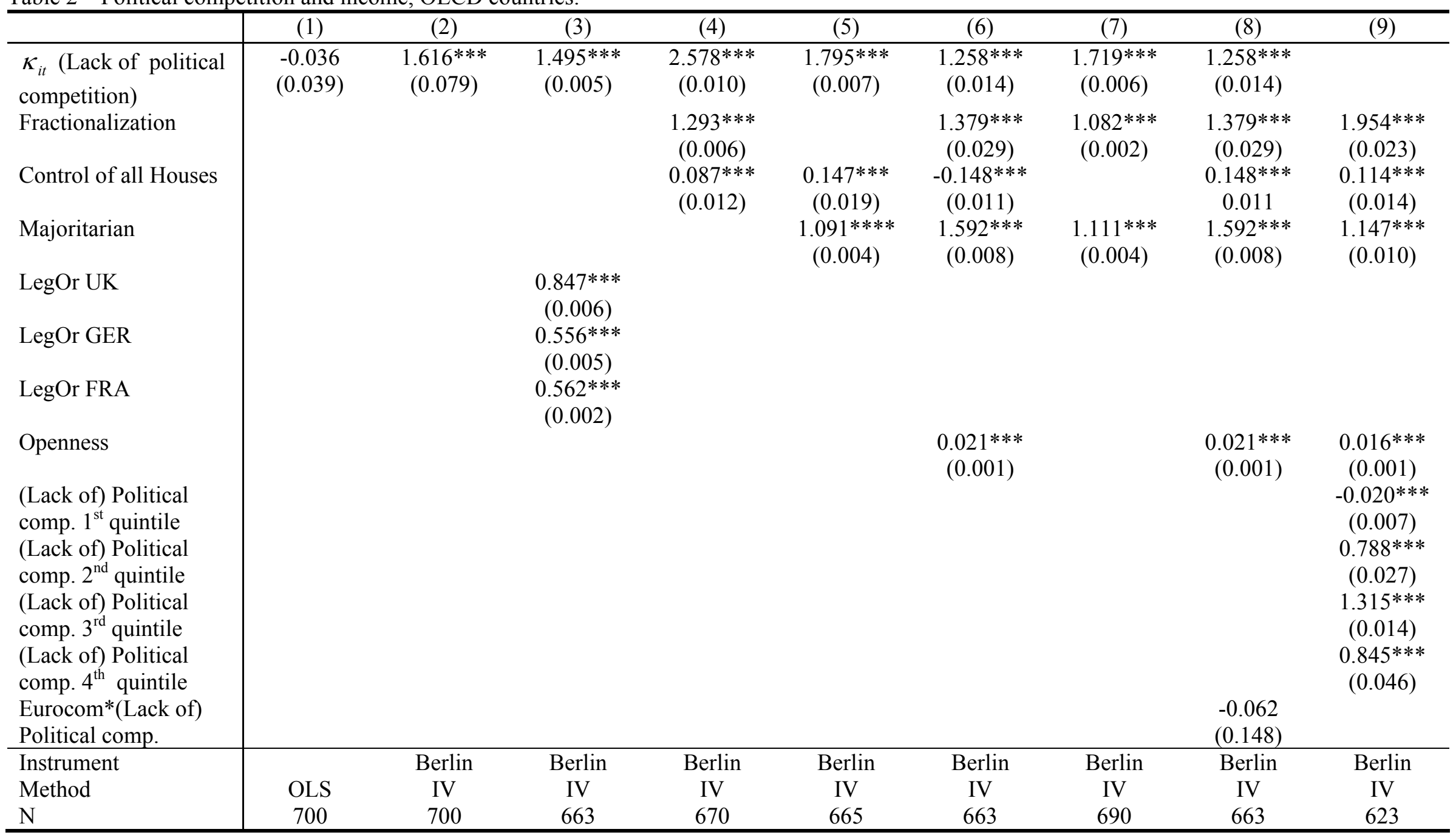

Numbers in parentheses are robust standard errors. ${ }^{* * *}$, and $* * *$ denote significance at $10 \%, 5 \%$, and $1 \%$ levels, respectively. All estimates include time- and countrydummy. 


\subsection{Growth equation}

We then consider a dynamic specification of model 1 to verify the effects of political competition on per capita income growth. Model 3 proposes a Barro augmented regression, that considers, besides the political and institutional variables introduced earlier (vector $\mathbf{Z}$ ), the initial level of output to capture convergence and a vector $\mathbf{E}$ of economic indicators, including the lagged share of investments over GDP, the share of government spending, and openness. The country and year dummies are unchanged. The specification is as follows (model 3):

$$
g y_{i t}=\gamma_{1} \kappa_{i t}+\gamma_{2} g y_{i 0}+\gamma_{3} \mathbf{Z}+\gamma_{4} \mathbf{E}+\vartheta_{i}+\theta_{t}+\xi_{i t}
$$

This dynamic specification serves two purposes, but must be considered under a caveat. The first and main purpose is to difference out any source of unobserved heterogeneity in levels of income. The fixed regional effects allows for long-term differences in average growth across countries. The second is to consider Solow-style convergence in incomes per capita, to rule out that changes in political competition are not picking up the fact that some countries grew faster just because they were initially poorer. As for the caveat, 27 years is probably too short a period to analyze the dynamics of personal income. There are wellknown issues from dynamic panels with fixed effects, especially when the number of time periods is not large. Having flagged these issues, we report the results of the estimates in Table 3.

Column 1 simply estimates the model of growth without political and institutional variables. We find evidence of convergence, and that investment and openness have positive and significant effect on growth. Including the measure of political competitiveness slightly changes the economic results by making government spending significantly negative, but the coefficient of political competition is negative but insignificant. In columns 3 through 5 the instrument Berlin is added, together with political and institutional variables, and our measure of political competition becomes negative and highly significant, again in contrast with the standard literature, but consistently with the predictions of our model for national governments. Column 6 finds poor evidence of non-linearity between political competition and growth, since all quintiles but one are significantly positive.

\subsection{Fiscal policy equation}

So far the results indicate that more political competition is associated with lower per capita income levels and slower growth. The model predicts that it be the case for national government, because the higher salience of ideological issues relatively to the subnational governments blunts the swing voters' responsiveness to the economic performance of the government; furthermore, the larger number of policy instruments available at the level of national government reduces the tax price of any policy decisions, which allows national politicians to use more fiscal resources to buy the votes of the non committed voters. This should appear as a positive correlation between political competition and distorsive fiscal policies at the level of national governments. To verify whether this is the case, we estimate the following model 4 :

$$
\mathbf{G}_{i t}=\delta_{1} \kappa_{i t}+\delta_{2} \mathbf{Z}+\delta_{3} \mathbf{E}+\vartheta_{i}+\theta_{t}+\psi_{i t}
$$

where the vector $\mathbf{G}_{i t}$ is composed by real per capita spending of country $i$ in time $t$ in a series of government programs specified below, and the left hand side variables are as before. In this case we only apply the IV strategy by using the fall of the Berlin Wall as an instrument. Table 4 reports the results. 
Table 3- Political competition and growth, OECD countries.

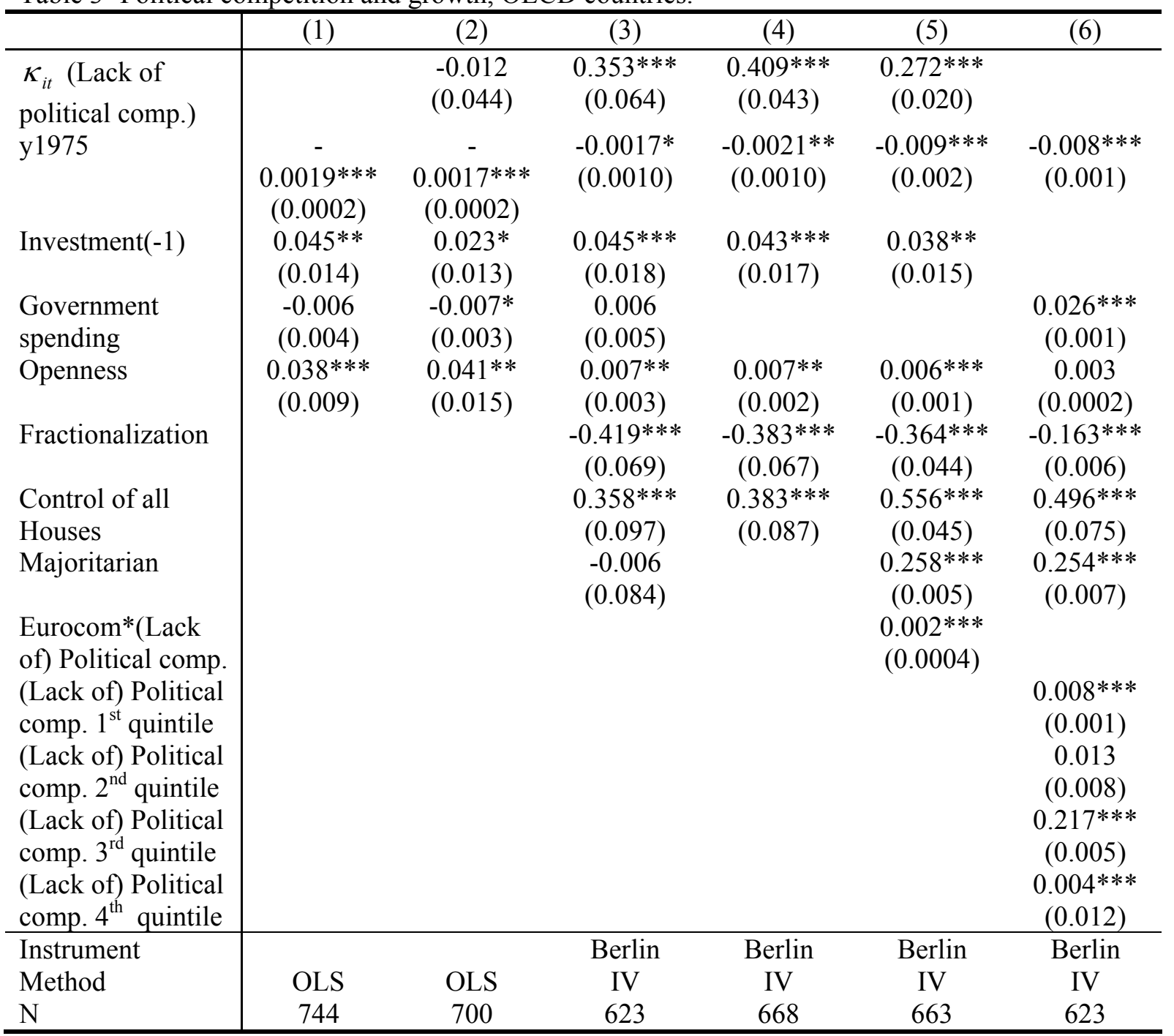

Numbers in parentheses are robust standard errors. *,**, and *** denote significance at 10\%, 5\%, and 1\% levels, respectively. All estimates include time- and country-dummy.

In column 1 we find that government consumption is positively affected by lack of political competition. The coefficient is sizable, and highly significant. We also find, in line with war of attrition models, that a more fragmented political system induces higher spending. Majoritarian voting systems reduce government spending, whereas the higher the share of the elderly the higher is public expenditure. Following Rodrick (1998) higher openness to international trade is associated with higher government spending as a way to insure against external shocks. When we consider other types of government spending, we still find a significantly positive effect, but this is reduced in size. This is true for redistributive spending, efficiency spending and indirect redistribution, all measured as share of GDP. 
Table 4- Political competition and fiscal policy, OECD countries.

\begin{tabular}{l|cccc}
\hline & $\begin{array}{c}(1) \\
\text { Government } \\
\text { consumption/GDP }\end{array}$ & $\begin{array}{c}(2) \\
\text { Redistributive } \\
\text { spending/GDP }\end{array}$ & $\begin{array}{c}(3) \\
\text { Efficiency } \\
\text { spending/GDP }\end{array}$ & $\begin{array}{c}(4) \\
\text { Indirect } \\
\text { redistribution/ } \\
\text { GDP }\end{array}$ \\
\hline$\kappa_{i t}$ (Lack of & $1.903^{* * *}$ & $0.268^{* * *}$ & $0.277^{* * *}$ & $0.237^{* * *}$ \\
political comp.) & $(0.054)$ & $(0.006)$ & $(0.006)$ & $(0.009)$ \\
Fractionalization & $1.039^{* * *}$ & $0.571^{* * *}$ & $0.803^{* * *}$ & $0.404^{* * *}$ \\
Control of all & $(0.123)$ & $(0.007)$ & $(0.004)$ & $(0.011)$ \\
Houses & $0.538^{* * *}$ & $-0.009^{* * *}$ & $-0.034^{* * *}$ & $-0.080^{* * *}$ \\
Majoritarian & $(0.069)$ & $(0.002)$ & $(0.002)$ & $(0.004)$ \\
& $-0.402^{* * *}$ & $0.471^{* * *}$ & $0.336^{* * *}$ & $0.461^{* * *}$ \\
Openness & $(0.016)$ & $(0.002)$ & $(0.048)$ & $(0.013)$ \\
& $0.034^{* * *}$ & $0.046^{* * *}$ & $0.016^{* * *}$ & $0.005^{* * *}$ \\
Share of the & $(0.001)$ & $(0.011)$ & $(0.003)$ & $(0.001)$ \\
Elderly & $0.732^{* * *}$ & $0.018^{* * *}$ & & $0.046^{* * *}$ \\
\hline Instrument & $(0.007)$ & $(0.002)$ & & $(0.001)$ \\
Method & Berlin & Berlin & Berlin & Berlin \\
$\mathrm{N}$ & $\mathrm{IV}$ & $\mathrm{IV}$ & $\mathrm{IV}$ & $\mathrm{IV}$ \\
\hline
\end{tabular}

Numbers in parentheses are robust standard errors. ${ }^{*}, * *$, and $* * *$ denote significance at $10 \%, 5 \%$, and $1 \%$ levels, respectively. All estimates include time- and country-dummy.

\section{Empirical analysis, Italian regions}

The Italian Regions provide an appropriate and interesting testing ground to the theory for three main reasons. First, the radical institutional reforms of 1995, which transformed their government structure from a parliamentary system elected via proportional representation to an effectively presidential one with an electoral system that effectively links the votes to a coalition to the preferences for a candidate for the Presidency of the Region are generally believed to have produced an upward shift in the competitiveness of Italian regional politics (Veronese, 2008). This discontinuity should make it easier to detect evidence of increased competition and the changes it induced on policy choices and economic efficiency. Second, the Italian regional governments have a limited set of political competencies, which should guarantee a fairly tight agency relationship between voters and their representatives. The preservation of political rents should therefore be more difficult for incumbent parties and politicians and this should foster political competition. Third, the limits in the policy choices should make it easier to evaluate their efficiency profile. Hence, in this paper we examine the main implications of the Besley et al. (2006) model on a sample of data drawn from the Italian Regions for the 1980-2002, centered on the 1995 institutional reform, which becomes our instrument as a dummy variable equal to 1 from 1995 to 2000, and 0 in the previous period.

\subsection{A brief description of Italian Regional politics and institutions}

The Italian Constitution, promulgated in 1948, foresees the principle of decentralization of the government functions and the establishment of Regional Governments (Article 5 and Title $\mathrm{V}$ of the Constitution). Italy has thus been divided into 20 Regions (see Appendix D for the list of names and abbreviations). Five of these, the first established between 1948 and 1963, enjoy a special statute (Regioni a Statuto Speciale, or RSS), because of their multilingual status, borderline position or particularly low level of development. The remaining 15 Regions, characterized by an 'ordinary statute' (Regioni a Statuto Ordinario, or RSO), were established in 1970, 22 years after the Constitutional provision. 
According to the Constitution, the major responsibilities of Regional Governments are those of health care and regional administration, plus certain aspects of social services, environment, local transportation, housing culture and tourism. The difference between the RSO and the RSS lies in the provision of grants from the Central Government, which is much more generous for the RSS (Brosio et al., 2003).

Until the early 1990s, the institutional framework and the politics of the RSO was based on proportional representation and on a parliamentary system, with a 5-year renewable tenure for Regional legislators. This created lack of accountability, instability of Regional governments and a general dissatisfaction with the quality of regional politics. This situation led to an important reform (law n. 43/1995) that modified both the electoral system and the length of tenure of regional legislators. The mechanism to elect the members of the regional Council switched from a pure proportional representation system to a mixed one. Eighty percent of the legislators are now elected on the basis of provincial lists and the remaining twenty percent by a majoritarian system on the basis of regional lists. Moreover, a top-up for the majority in two steps ensures that the absolute majority of the legislators is held by the coalition linked to the regional list that obtained the relative majority of the votes. The reform also reduced the tenure length of the Council from five to two years if the confidence relationship between the Council and the Cabinet breaks down during the first two years. Finally, the President is not elected directly but is indicated before the election by the coalition that supports her or him. The new electoral rules were first applied in the 1995 regional elections. In 1999, a further reform step was introduced: a constitutional law modified the election of the President (art. 122 of the Constitution), stating that the President of the Regional Government is elected by universal and direct suffrage, unless the Regional Statute establishes otherwise. The elected President appoints and dismisses the members of the Regional Government. The first direct election of the President took place in the regional elections of the year 2000 .

This reform has considerably affected the ways and mores of Italian regional politics. Alternation in government, already present, increased significantly in the three elections held under the new institutional system. To give an example, in the last electoral round, 5 regions out of 20 (Calabria, Lazio, Piemonte, Puglia and Sardegna) swung from a center-right to a center-left coalition, a remarkable shift given the traditional stability of Italian politics until $1995 .^{8}$

Another factor that increased political competition was the dramatic political changes that took place in Italy at the beginning of the 1990s, when a wave of corruption scandals swept away the pre-existing political parties. Especially at the level of national politics, these parties enjoyed large political rents because of the impossibility of the Communist Party to alternate in government with the Christian Democrats. Though since 1948 the Communist Party has always been the second largest party in Italy, its declared incompatibility with Italy's international alliances made the Communist Party an unreliable member of Italian national government. When this stalemate broke down after the fall of the Berlin Wall, it was replaced by a system of new parties, aggregating into two coalitions, usually called the Polo (CentreRight) and the Ulivo (Centre-Left), alternating in government both at the national and at the regional level.

Research about the effects of the 1995 institutional reforms on the competitiveness of Italian regional politics and on the economic performance of the Regions is virtually nonexistent. Veronese (2008) tests predictions along the lines of Besley et al. (2006) on data on Italian local governments, which underwent a similar move from parliamentarism to

\footnotetext{
${ }^{8}$ In the time-span we consider, among RSOs, two regions in the North (Lombardy and Veneto), four regions in the Center (Emilia Romagna, Tuscany, Marche and Umbria), and two regions in the South (Campania and Basilicata) did not change the ruling coalition.
} 
presidentialism in 1993. She finds evidence that the institutional reform generated more political competition and greater accountability, measured as an increase in the differentiation between the executive and the legislative branch. This differentiation is in turn correlated with more, not less, government spending.

\subsection{Empirical strategy}

We consider the relationship between political competition, on the one hand, and income levels and public spending, on the other. To this end, we use the electoral margin between the two largest parties until 1995 elections and the margin between the two coalitions for the following elections as the indicator of political competition. We take the 1995 institutional reform as the exogenous shock to the political rents that possibly existed during the pre-1995 parliamentary regime. In this way, political competition is considered as a long-run, structural phenomenon, affected by structural events like institutional reforms characterized by considerable durability, rather than as the outcome of day-to-day policy struggles or of electoral contests. We also resort to fixed effects and year dummies, to get rid of conditioning phenomena not directly related with the political competition-economic performance relationship, and use a series of control variables to 'clean' the estimates as much as possible. Finally, given the crucial role of the institutional reform of 1995 in our estimates, we limit the sample to the 15 Regions with an Ordinary Statute (RSO), since they were the only ones to be affected by the reform. We will thus investigate the link between political competition and economic performance by looking at the policy choices of the Regions. To rule out problems of reverse causation, we estimate the model using an IV technique, which models political competition using drivers that are plausibly independent from economic development. ${ }^{9}$ Table 5 reports the summary statistics of the variables involved in the analysis. Appendix $\mathrm{C}$ describes the data sources.

Table 5. Summary statistics - Italian Regions sample

\begin{tabular}{|c|c|c|c|c|}
\hline & Mean & Std. Dev. & Min. & Max \\
\hline$\kappa_{i t}$ (lack of political competition, margin seats) & 0.216 & 0.116 & 0.000 & 0.500 \\
\hline$\kappa_{i t}$ (lack of political competition, margin votes) & 0.141 & 0.107 & 0.001 & 0.447 \\
\hline Election & 0.235 & 0.424 & 0.000 & 1.000 \\
\hline Fractionalization & 0.361 & 0.110 & 0.178 & 0.580 \\
\hline Total gov. expenditures per capita & 4294.5 & 2482.1 & 0.000 & 11697 \\
\hline Health care expenditure per capita & 1411.2 & 494.63 & 554.85 & 2540.1 \\
\hline Expenditures in public admin. per capita & 126.33 & 92.088 & 27.565 & 595.97 \\
\hline Margin Seats $1^{\text {st }}$ Quintile & 0.153 & 0.359 & 0.000 & 1.000 \\
\hline Margin Seats $2^{\text {nd }}$ Quintile & 0.212 & 0.409 & 0.000 & 1.000 \\
\hline Margin Seats $3^{\text {rd }}$ Quintile & 0.427 & 0.495 & 0.000 & 1.000 \\
\hline Margin Seats $4^{\text {th }}$ Quintile & 0.109 & 0.303 & 0.000 & 1.000 \\
\hline Margin Seats $5^{\text {th }}$ Quintile & 0.106 & 0.308 & 0.000 & 1.000 \\
\hline Margin Votes $1^{\text {st }}$ Quintile & 0.365 & 0.481 & 0.000 & 1.000 \\
\hline Margin Votes $2^{\text {nd }}$ Quintile & 0.294 & 0.456 & 0.000 & 1.000 \\
\hline Margin Votes $3^{\text {rd }}$ Quintile & 0.251 & 0.433 & 0.000 & 1.000 \\
\hline Margin Votes $4^{\text {th }}$ Quintile & 0.031 & 0.174 & 0.000 & 1.000 \\
\hline Margin Votes $4^{\text {th }}$ Quintile & 0.059 & 0.235 & 0.000 & 1.000 \\
\hline
\end{tabular}

\footnotetext{
${ }^{9}$ The sample of the Italian Regions does not allow checking the quality of the Presidents as Besley et al. (2006) do, namely, interpreting high quality State Governors as those associated with above trend Regional incomes. In Italy, the Presidents of the Regions are de facto directly elected since 1995 (de jure since 2000); the short time series does not allow enough degrees of freedom for that type of analysis. Data about the expenditure levels of Regional spending programs are however available until the year 2000.
} 


\subsection{Income levels}

To model the relationship between income levels and political competition, we estimate the following model:

$$
y_{i t}=\alpha_{1} \kappa_{i t}+\alpha_{2} \mathbf{Z}+v_{i}+u_{t}+\varepsilon_{i, t},
$$

where $y_{i t}$ is the $\log$ of real income per capita in region $i$ at time $t, v_{i}$ is a region fixed effect, $u_{t}$ is a time-dummy, and $\varepsilon_{i t}$ is the error term. Our key variable is $\kappa_{i t}$, the indicator of political competition, which, in the empirical analysis, is captured by the difference in votes between the first and the second largest parties for the elections before 1995, and between the winning and the losing coalition for the elections after 1995. Two control variables compose the $\mathbf{Z}$ vector. ${ }^{10}$ First, to verify whether is pre- or post-electoral political competition to matter, we estimate equation (5) in terms of both margin of seats held in the Regional Council by the winning party and of margin of votes obtained in the elections over the second largest party. The first margin captures the 'parliamentary majority' of the President and is thus relevant for policy decisions; the second more closely proxies his/her electoral base, and can be more informative for political decisions, such as whether to compete for another mandate or not. Second, as for the OECD sample, we add a political fragmentation variable. All models are log linear and coefficients are estimated using robust standard errors clustered by regions that allow for region specific serial correlation.

Column (1) in Table 6 displays estimates of (5) by OLS for annual data between 1980 and 2002. There is evidence of a weakly significant (10\% level) negative correlation between political competition, measured in terms of seat margins, and income per-capita. This result is not conclusive, because the coefficient $\alpha_{1}$ gives us the causal effect of political competition on $y_{i t}$ as long as $\kappa_{i t}$ is uncorrelated with $\varepsilon_{i t}$. In the context of our analysis, this condition may fail because of omitted factors influencing both economics and politics. The institutional reform of 1995 may have destroyed pre-existing political rents and increased competition because under the new system voters felt that they could 'choose' the Regional government instead of seeing it emerge from party politics, as it was the case under the previous institutional framework. The disappearance of the old political parties and the (slow) emergence of the two new coalitions might have contributed to reinforce political competition: average voting turnout of regional elections in fact increased after 1995. At the same time, the new political setup emerging after the wave of scandals of the early 1995 could have reduced corruption and liberated resources to be invested in the productive sectors, thereby raising output independently, although there is no decisive evidence of such an outcome (Golden and Picci, 2005).

Furthermore, as already pointed out, it could also be the case that higher income stimulates political competition, thereby rising problems of reverse causation. To solve these potential problems, we resort to an IV strategy. We instrument political competition by introducing a dummy for the 1995 year, which takes the value of 0 before and 1 afterwards. This dummy captures both the institutional reform of 1995 and the fact that the ensuing Regional elections were contested by two coalitions of parties organized before the elections, instead of a constellation of parties that form the governing and opposing coalitions after the elections. These changes are plausibly independent of economic change.

\footnotetext{
${ }^{10}$ We have tried a battery of control variables, including government partisanship, the ratio between the transfers received from the central government and the Region's total revenues, as well as other specification of the electoral budget cycle. We report only those who more consistently turn out significant in the analysis.
} 
Table 6 - Political competition and personal income, Italian regions

\begin{tabular}{|c|c|c|c|c|c|c|}
\hline & $(1)$ & (2) & (3) & (4) & (5) & (6) \\
\hline $\begin{array}{l}\kappa_{i t} \text { (lack of political } \\
\text { comp., margin seats) }\end{array}$ & $\begin{array}{c}-1.5613 * \\
(0.852)\end{array}$ & $\begin{array}{c}-2.135 * * * \\
(0.097)\end{array}$ & & & & \\
\hline $\begin{array}{l}\kappa_{i t} \text { (lack of political } \\
\text { comp., margin votes) }\end{array}$ & & & $\begin{array}{l}-3.258 \\
(6.614)\end{array}$ & $\begin{array}{c}-1.538^{* * * *} \\
(0.482)\end{array}$ & & \\
\hline Election & $\begin{array}{l}1.571^{*} \\
(0.867)\end{array}$ & $\begin{array}{c}1.027 * * * \\
(0.037)\end{array}$ & $\begin{array}{c}1.315 \\
(1.224)\end{array}$ & $\begin{array}{c}1.164 * * * \\
(0.235)\end{array}$ & $\begin{array}{c}1.531 * * * \\
(0.277)\end{array}$ & $\begin{array}{c}1.020 * * * \\
(0.356)\end{array}$ \\
\hline Fractionalization & $\begin{array}{l}-2.329 \\
(1.777)\end{array}$ & $\begin{array}{c}-2.985 * * * \\
(0.877)\end{array}$ & $\begin{array}{l}-1.754 \\
(1.176)\end{array}$ & $\begin{array}{c}-1.043 * * \\
(0.431)\end{array}$ & $\begin{array}{c}-1.175^{* *} \\
(0.336)\end{array}$ & $\begin{array}{c}-1.134 * * \\
(0.547)\end{array}$ \\
\hline Margin Seats $1^{\text {st }}$ & & & & & $-1.354^{* *}$ & \\
\hline Quintile & & & & & $(0.519)$ & \\
\hline Margin Seats $2^{\text {nd }}$ & & & & & $-0.660 * * *$ & \\
\hline Quintile & & & & & $(0.062)$ & \\
\hline Margin Seats $3^{\text {rd }}$ & & & & & $-1.183 * * *$ & \\
\hline Quintile & & & & & $(0.094)$ & \\
\hline Margin Seats $4^{\text {th }}$ & & & & & $1.371 * * *$ & \\
\hline Quintile & & & & & $(0.164)$ & \\
\hline Margin Votes $1^{\text {st }}$ & & & & & & $-1.651 * * *$ \\
\hline Quintile & & & & & & $(0.524)$ \\
\hline Margin Votes $2^{\text {nd }}$ & & & & & & $-0.656 * *$ \\
\hline Quintile & & & & & & $(0.276)$ \\
\hline Margin Votes $3^{\text {rd }}$ & & & & & & $1.753 * *$ \\
\hline Quintile & & & & & & $(0.675)$ \\
\hline Margin Votes $4^{\text {th }}$ & & & & & & $-1.502 * * *$ \\
\hline Quintile & & & & & & $(0.144)$ \\
\hline $\mathrm{N}$ & 255 & 255 & 255 & 255 & 255 & 255 \\
\hline Estimation method & OLS & IV & OLS & IV & IV & IV \\
\hline Instrument & & D1995 & & D1995 & D1995 & D1995 \\
\hline
\end{tabular}

Numbers in parentheses are robust standard errors. *, **, and *** denote significance at $10 \%, 5 \%$, and $1 \%$ levels, respectively. All estimates include time- and region-dummy.

Given the nature of the variables (lower margins indicate greater competition) this bias may be responsible for the "wrong" sign obtained in OLS estimates. We thus consider a firststage equation:

$$
\kappa_{i t}=r_{i}+s_{t}+\beta_{1} d 1995+\eta_{i t}
$$

where $r_{i}$ is a region fixed effect and $s_{t}$ a year fixed effect. The instruments $d 1995$ is a year dummy that discriminates between elections before and after 1995. Results from the IV version corresponding to (5), using (6) as the first stage, are found in column (2). The estimated $\alpha_{1}$ coefficient in this case is negative and statistically significant, suggesting that in the new institutional setting, increased political competition has a positive casual effect on regional per capita income. The change of coefficient from the OLS to the IV estimates seems to be attributable to the bias in the OLS estimates of column (1). The estimates of columns (3) and (4) repeat the same exercise, with quite similar result, using votes' margins as the indicator of political competition. The OLS estimated coefficient $\alpha_{1}$ is not statistically significant, while the IV one has the correct sign and is significant at the $1 \%$ level. Post electoral politics seems to matter more in terms of economic performance, because the sign of the $\alpha_{1}$ coefficient in column (2), where $\kappa_{i t}$ is estimated in terms of seat margins, is $40 \%$ larger than that of column (4), where $\kappa_{i t}$ is in terms of vote margins. Policies seem to affect regional personal income more than political circumstances. The estimates reveal evidence of war of attrition among the parties that support the regional government (the coefficient on 
fractionalization is always negative and statistically significant in the IV estimates), as well as of a political business cycle: electoral years coincide with above average levels of per capita income. Finally, the relationship between political competition and economic performance may be nonlinear. To test for it, we divide the vote and seat margins in quintiles and categorize the Regions by means of a dummy variable that equals 1 if the Region belongs to that quintile and 0 otherwise. The first quintile includes the largest margins (lowest competition), the fifth the smallest ones and is used as intercept benchmark in the estimates. Columns (5) and (6) report the results for seats and votes margins, respectively. Nonlinearity seems more pronounced in the case of votes (column 6) than of seats (column 5), where nonlinearity is determined only by the effects of Regions in the lowest quintiles. The switch from the continuous variable to the dummies does not affect the signs and size of the coefficients of the other regressors.

\subsection{Fiscal policy}

So far the results indicate that more political competition is associated with higher income levels and growth. Now we must examine whether this correlation is due to more efficiently-oriented policy choices of the Regional governments.

As noted in Section 3, Italian Regions have the main responsibility of two spending programs, health care and regional administration. They share the responsibility of efficiencyaugmenting programs, such as transport and education, with other government levels. In the spirit of the model, we focus our attention on the two programs for which the responsibility can be more directly and exclusively attributed to the Regional governments. As neither of these programs directly stimulates economic performance, rather are characterized by high levels of waste and pork-barrel spending, we reinterpret the prediction of the model postulating that tighter political competition should be associated with lower spending in healthcare and even more in regional administration. In other words, high quality politicians signal their competence by reducing waste in healthcare spending and by streamlining the regional bureaucracy, and vice versa. To gauge some information about the other programs, we test the implications of the model on total regional spending as well. As already explained in section 3, the institutional reforms of the 1995 and 2001 expanded the set of responsibilities of the Regions in the second half of the sample, which should result in an upward shift of the intercept of public spending. The IV estimates, instrumenting for the 1995 reform, should capture this effect and still yield unbiased estimates.

The model that we estimate is specified as follows:

$$
\mathbf{G}_{i t}=\delta_{1} \kappa_{i t}+\delta_{2} \mathbf{Z}+v_{i}+u_{t}+\psi_{i t}
$$

where the vector $\mathbf{G}_{i t}$ is composed by total real per capita spending of Region $i$ in time $t$, real spending per capita in healthcare, and real spending per capita in administration. Table 7 reports the IV results for the three dependent variables in column (1), (2) and (3), respectively, ${ }^{11}$ where $\kappa_{i t}$ is expressed in terms of seat margins, and in column (4), (5) and (6), where $\kappa_{i t}$ in expressed in terms of vote margins.

The bottom line is that tighter political competition does decrease public spending per capita, both in total terms and for what it concerns spending for health care and for regional administration. Because of the presence of waste, rent seeking, pork barrel and common pool situations in Italian government spending, this result runs is consistent with the prediction of

\footnotetext{
${ }^{11}$ We have estimated also the OLS specification and found the same downward bias detected in the regression for the income levels, most likely due to the same reasons. We have therefore omitted reporting the OLS estimates.
} 
Besley et al. (2006), that more competition promotes efficiency enhancing policies. Regional fixed effects rule out the possibility that the estimates of equation (8) are due to the level of economic development of the Region or to any other Region specific factor. Year fixed effect deprive the estimates of the influence of the business cycle. The other regressors included in the $\mathbf{Z}$ vector are also in line with theory. Electoral years are characterized by higher spending and more fragmented coalitions tend to spend more to solve problems of war of attrition. In the two programs of public expenditures on which Regional governments have a more direct control the $\delta_{1}$ coefficient on seat margin is larger than on vote margins: $15 \%$ larger in the case of health care and almost $60 \%$ in the case of public administration. These results are consistent with the idea that waste characterizes these programs; they are also plausible, as the size of the coefficient is larger where the Regional government has a more direct responsibility. Finally, they suggest that the reform of 1995 strengthened the control of the President of the Region over his majority, thereby creating incentives for the delivery of more efficiency oriented policy choices.

Table 7- Political competition and fiscal policy, Italian regions

\begin{tabular}{|c|c|c|c|c|c|c|}
\hline $\begin{array}{l}\text { Dependent } \\
\text { variable }\end{array}$ & $\begin{array}{l}\text { Total exp per } \\
\text { capita }\end{array}$ & $\begin{array}{l}\text { Healthcare } \\
\text { exp. per } \\
\text { capita }\end{array}$ & $\begin{array}{l}\text { Exp. in } \\
\text { public } \\
\text { admin. per } \\
\text { capita }\end{array}$ & $\begin{array}{l}\text { Total gov. } \\
\text { exp. per } \\
\text { capita }\end{array}$ & $\begin{array}{l}\text { Health care } \\
\text { exp. per } \\
\text { capita }\end{array}$ & $\begin{array}{l}\text { Exp. in } \\
\text { public } \\
\text { admin. per } \\
\text { capita }\end{array}$ \\
\hline & $(1)$ & (2) & (3) & (4) & (5) & (6) \\
\hline $\begin{array}{l}\kappa_{i t} \text { (lack } \\
\text { of political } \\
\text { comp, } \\
\text { margin } \\
\text { seats) }\end{array}$ & $\begin{array}{c}- \\
1093.419^{* * *} \\
(31.217)\end{array}$ & $\begin{array}{c}- \\
702.061 * * * \\
(31.684)\end{array}$ & $\begin{array}{c}- \\
179.653 * * * \\
(32.094)\end{array}$ & & & \\
\hline $\begin{array}{l}\kappa_{i t}(\text { lack } \\
\text { of political } \\
\text { comp., } \\
\text { margin } \\
\text { votes) }\end{array}$ & & & & $\begin{array}{c}- \\
1565.78 * * * \\
(123.783)\end{array}$ & $\begin{array}{c}- \\
613.295^{* * *} \\
(20.851)\end{array}$ & $\begin{array}{c}- \\
113.017^{* * *} \\
(34.822)\end{array}$ \\
\hline Election & $\begin{array}{c}678.196 * * * \\
(70.100)\end{array}$ & $\begin{array}{c}230.576 * * * \\
(55.164)\end{array}$ & $\begin{array}{c}25.987 * * * \\
(3.104)\end{array}$ & $\begin{array}{c}811.434 * * * \\
(68.27)\end{array}$ & $\begin{array}{c}276.119 * * * \\
(44.397)\end{array}$ & $\begin{array}{c}33.2336 * * * \\
(12.646)\end{array}$ \\
\hline $\begin{array}{l}\text { Fractionali } \\
\text { zation }\end{array}$ & $\begin{array}{c}523.84 * * * \\
(74.683) \\
\end{array}$ & $\begin{array}{c}167.30 * * * \\
(19.612) \\
\end{array}$ & $\begin{array}{c}86.617 * * * \\
(13.746) \\
\end{array}$ & $\begin{array}{c}508.454 * * * \\
(110.306) \\
\end{array}$ & $\begin{array}{c}195.44 * * * \\
(8.643)\end{array}$ & $\begin{array}{c}57.630 * * * \\
(8.998) \\
\end{array}$ \\
\hline $\mathrm{N}$ & 255 & 243 & 244 & 255 & 243 & 244 \\
\hline
\end{tabular}

All estimates are obtained by the IV method, with D1995 as instrument. Numbers in parentheses are robust standard errors. $*, * *$, and $* * *$ denote significance at $10 \%, 5 \%$, and $1 \%$ levels, respectively. All estimates include time- and region-dummy.

\section{Conclusions}

In this paper we have tested the main predictions of Besley et al. (2006) in a context as close as possible to the theoretical model, to verify its ability to explain situations other than the development of the Southern States of the U.S. In many ways the Italian Regions underwent a similar historical evolution, as the institutional reforms of 1995 and the changes of the political actors of the early 1990s destroyed political rents and provided a one and for all stimulus to political competition, just like the Right to Vote Acts of 1965-1970 did in the American South. This ensures that in both contexts political competition is interpreted in terms of long run structural events, not as short run electoral outcomes, a relevant feature that is often missing in the empirical literature related to the model of Besley et al. (2006). The remaining institutional differences that remain between the Italian regions and U.S. States are 
a test for the generality of the theory. The estimates generally lend empirical support to the predictions of the theory. There is evidence of a positive correlation between political competition and economic performance of the Italian Regions, as well as of that more political competition forces Regional governments to make efficiency-enhancing policy choices.

The current panorama of the empirical literature sees the theory of Besley et al. (2006) being confirmed at the level of sub-central governments in various contexts - the U.S. States, the Flemish municipalities (Ashworth et al., 2006), and now the Italian Regions - but not at the level of national governments. There, in a panel of OECD countries, Padovano and Ricciuti (2007) find evidence that greater political competition is correlated with an increase of short-term, redistributive policy choices, aimed at buying votes, which depress economic performance.

This dichotomy of empirical findings suggests that future research should move along two avenues. The first is to insist in the empirical analysis, to verify that the dichotomy persist when new samples are examined and other testing procedures are explored. The second avenue is theoretical, as it departs from the acceptance of the dichotomy and moves towards a more articulate description of the link between political competition and economic performance. In other words, the link evidenced by Besley et al. (2006) might hold in certain institutional contexts, but could be less relevant in others, i.e., it might be institutions sensitive. This might explain why at the level of national governments greater political competition seems to stimulate less efficiency-oriented fiscal policies, but at the level of subcentral governments it does not. This may be due to a variety of factors, one being that there are tighter constraints on the discretionary power of politicians of sub-central governments, in the forms of yardstick competition, of tighter control from higher government levels, of a more limited set of competencies that reduces voters' information costs, or of a lower salience of ideological issues. Another may be that national governments have a wider array of competencies, which multiply the number of dimensions along which parties and candidates may compete and exchange in order to stifle political competition. In other words, national political markets are closer to a setting of monopolistic competition whereas sub-national ones are closer to perfect competition. Be that as it may, in that $\kappa_{i t}$ there seems to be more than has met the eyes of Besley et al. (2006). 


\section{References}

Alesina, A. and Tabellini, G. (2008) "Bureaucrats or Politicians? Part II: Multiple Tasks" Journal of Public Economics, forthcoming.

Alesina, A. and Tabellini, G. (2007) "Bureaucrats or Politicians? Part I: A Single Task" American Economic Review 97: 169-179.

Alesina, A. and Drazen, A. (1991), "Why Are Stabilizations Delayed? A Political Economy Model", American Economic Review 81: 1170-1188.

Ashworth, J., Geys, B., Heyndels, B. and Wille, F. (2006), "Political Competition and Local Government Performance: Evidence from Flemish Municipalities", mimeo.

Barro, R. J. (1973) "The Control of Politicians: An Economic Model”, Public Choice 14: 1942.

Barro, R. J. (1996) "Democracy and Growth", Journal of Economic Growth 1: 1-96.

Barro, R. J. and Sala-i-Martin, X. (2004), Economic Growth II ed., New York, McGraw-Hill.

Beck, T., Clarke, G., Groff, A., Keefer, P., and Walsh, P. (2001). "New tools in comparative political economy: The Database of Political Institutions", World Bank Economic Review, 15: 165-176.

Becker, G. S. (1958), "Competition and Democracy", Journal of Law and Economics 1: 105109.

Becker, G. S. (1983), "A Theory of Competition Among Pressure Groups for Political Influence", Quarterly Journal of Economics 97: 371-400.

Besley, T. and Coate, S. (1997), "An Economic Model of Representative Democracy," Quarterly Journal of Economics 112: 85-114.

Besley, T., Persson, T., and Sturm, D. (2006), "Political Competition and Economic Performance: Theory and Evidence from the United States", mimeo.

Brosio, G., Maggi, M. and Piperno, S. (2003), Governo e Finanza Locale III ed., Torino, Giappichelli.

Downs, A. (1957). An Economic Theory of Democracy, New York, Harper and Row.

Giavazzi, F. and Tabellini, G. (2005), "Economic and Political Liberalizations", Journal of Monetary Economics 52: 1297 -1330

Golden, M. and Picci, L. (2005) "Corruption and the Management of Public Works in Italy," in: S. Rose-Ackerman (ed.), Handbook of Economic Corruption, Cheltenham, Edward Elgar.

Krusell, P. and Rios-Rull, J. V. (1996) "Vested Interests in a Positive Theory of Stagnation and Growth", Review of Economic Studies 63: 301-329.

La Porta, R., Lopez-de-Silanes, F., Shleifer, A., and Vishny, R. (1999), "The Quality of Government", Journal of Law, Economics and Organization 15: 222-279.

McCormick, R. E. and Tollison, R. D. (1981) Politicians, Legislation and the Economy: An Inquiry into the Interest-Group Theory of Government, Boston, Martinus Nijhoff.

Padovano, F. (2007), The Politics and Economics of Regional Transfers, Cheltenham: Edward Elgar.

Padovano, F. and Ricciuti, R. (2007) "Political Competition and Economic Performance: Evidence from the OECD Countries", mimeo.

Persson, T. and Tabellini, G. (2003). The Economic Effects of Constitutions. Cambridge, MIT Press.

Persson, T. and Tabellini, G. (2000), Political Economics: Explaining Economic Policy, Cambridge, MA: MIT Press.

Polo, M. (1998), "Electoral Competition and Political Rents", mimeo, IGIER, Bocconi University. 
Przeworski, A., Alvarez, M., Cheibub, J. A., and Limongi, F. (2000). Democracy and Development: Political Regimes and Economic Well-being in the World, 1950-1990. New York: Cambridge University Press.

Stigler G. J (1972), "Economic Competition and Political Competition" Public Choice 13: 91106.

Svensson, J. (1998), “Controlling Spending: Electoral Competition, Polarization, and Primary Elections", Mimeo, The World Bank.

Veronese, B. (2008), "How Do Institutions Shape Policy Making? The Transition from Parliamentarism to Presidentialism in Italian Local Governments", in F. Padovano and R. Ricciuti (eds.) Italian Institutional Reforms. A Public Choice Approach, New York, Springer.

Wintrobe, R. (1998). "Democracy and Dictatorship", in S. Borner, M. Paldam, and J. Vargas (Eds.), The Political Dimension of Economic Growth, Macmillan for the International Economics Association.

Wintrobe, R. (2007), “Authoritarianism”, in C. Boix and S. Stokes (eds.) Oxford Handbook of Comparative Politics, Oxford, Oxford University Press (forthcoming).

Wittman, D. (1989), "Why Democracies Produce Efficient Results", Journal of Political Economy 97: 1395-1424.

Wittman, D. (1995), The Myth of Democratic Failure: Why Political Institutions are Efficient, Chicago, University of Chicago Press. 


\section{APPENDIX A:}

As $H_{c c}$ is negative, we get a savings function, $k^{I}=K(\beta \tau)$, which defines per capita investment as a declining function of the overall tax incidence on the new sector. As $Q_{k k}<0$, however, per capita investment in the traditional sector is an increasing function of the tax pressure on the new sector, $k^{T}=K^{T}(\beta \tau)$. Moreover, this implies that the quasi-rents to the owners of the traditional factor $R(\beta \tau)=Q_{l}\left(K^{T}(\beta \tau), l\right)$ are an increasing function of the tax as $Q_{l k}>0$. Substituting this information into the utility function $V^{I}$ yields $V^{I}(\beta \tau)=F(\beta \tau)+R(\beta \tau)\left(l^{I}-l\right), \quad$ where $\quad F(\beta \tau) \quad$ is defined as $F(\beta \tau)=H\left(y_{1}-K(\beta \tau)\right)+A\left(K(\beta \tau)-K^{T}(\beta \tau)\right)+Q\left(K^{T}(\beta \tau), l\right)$ and where we have used the per capita budget constraint: $f=\beta \tau A\left(K(\beta \tau)-K^{T}(\beta \tau)\right)$. The expression $F(\beta \tau)$ is the indirect utility of a hypothetical person, who owns the average per capita amount of the traditional asset. The indirect utility function $V^{I}$ illustrates the conflict of interest between owners of the traditional asset and owners of the new asset. Since $F_{\tau}(0)=0$ and $R_{\tau}(0)>0$, those who own an amount of the traditional asset above the mean prefer a strictly positive value of $\beta \tau$, even though a positive tax pressure depresses the return to capital. The utilitarian optimum is to set $\tau=0$, as average utility has a maximum at the point $\tau=0$ (see Besley et al (2006) for the demonstration that these are global maxima).

\section{APPENDIX B:}

The preferences of an elected President, at the point where he sets policy, can thus be written as $V(q, \beta \tau, t)=V^{K}(\beta \tau)+(1+\rho)(1-q) t \alpha M+\Delta=F(\beta \tau)-R(\beta \tau) l+(1+\rho)(1-q) t \alpha M+\Delta$. The party share of transfers is split equally between members. Let the number of party members (in each party) be $m M$ with $m<\frac{1}{2}(1-\sigma)$ and denote the average quality of party members by $q^{P}$. Parties maximize the indirect utility of the average member under the hypothesis that $\frac{\rho}{m}\left(1-q^{P}\right)>1$.

\section{APPENDIX C: DATA SOURCES}

Economic data for the OECD countries are taken from Penn World Tables, Release 6.2. Political data are from Database of Political Institutions, while data about the level and composition of public spending are from Perrson and Tabellini (2003), downloadable from www.igier.unibocconi.it. Economic data for the Italian Regions are drawn from the CRENOS database (www.crenos.it) and ISTAT, (ISTAT (various years) I Conti Economici delle Regioni, Roma ISTAT). Data on political results are from the database of Ministero dell'Interno (www.interno.it), while those on public spending by the Regions are again from ISTAT. 
APPENDIX D: LIST AND TYPE OF STATUTE OF THE ITALIAN REGIONS

\begin{tabular}{|l|l|l|l|}
\hline N. & AREA & NAME & STATUTE \\
\hline 1 & North & Val d'Aosta & Special \\
\hline 2 & North & Piedmont & Ordinary \\
\hline 3 & North & Lombardy & Ordinary \\
\hline 4 & North & Trentino-Alto Adige & Special \\
\hline 5 & North & Veneto & Ordinary \\
\hline 6 & North & Liguria & Ordinary \\
\hline 7 & North & Friuli-Venezia Giulia & Special \\
\hline 8 & Center & Emilia Romagna & Ordinary \\
\hline 9 & Center & Toscana & Ordinary \\
\hline 10 & Center & Marche & Ordinary \\
\hline 11 & Center & Umbria & Ordinary \\
\hline 12 & Center & Lazio & Ordinary \\
\hline 13 & Center & Abruzzo & Ordinary \\
\hline 14 & South & Campania & Ordinary \\
\hline 15 & South & Molise & Ordinary \\
\hline 16 & South & Puglia & Ordinary \\
\hline 17 & South & Basilicata & Ordinary \\
\hline 18 & South & Calabria & Ordinary \\
\hline 19 & South & Sicilia & Special \\
\hline 20 & South & Sardinia & Special \\
\hline
\end{tabular}




\section{CESifo Working Paper Series}

for full list see www.cesifo-group.org/wp

(address: Poschingerstr. 5, 81679 Munich, Germany, office@cesifo.de)

2349 Lammertjan Dam and Ben J. Heijdra, The Environmental and Macroeconomic Effects of Socially Responsible Investment, July 2008

2350 Avner Greif, Contract Enforcement and Institutions among the Maghribi Traders: Refuting Edwards and Ogilvie, July 2008

2351 Helmuth Cremer, Philippe De Donder, Dario Maldonado and Pierre Pestieau, Habit Formation and Labor Supply, July 2008

2352 Francesco Menoncin and Paolo M. Panteghini, The Johansson-Samuelson Theorem in General Equilibrium: A Rebuttal, July 2008

2353 Michael Kaganovich and Itzhak Zilcha, Alternative Social Security Systems and Growth, July 2008

2354 Keith Blackburn, Kyriakos C. Neanidis and M. Emranul Haque, Corruption, Seigniorage and Growth: Theory and Evidence, July 2008

2355 Edward Castronova, A Test of the Law of Demand in a Virtual World: Exploring the Petri Dish Approach to Social Science, July 2008

2356 Harald Badinger and Peter Egger, GM Estimation of Higher-Order Spatial Autoregressive Processes in Cross-Section Models with Heteroskedastic Disturbances, July 2008

2357 Wolfgang Buchholz and Jan Schumacher, Discounting the Long-Distant Future: A Simple Explanation for the Weitzman-Gollier-Puzzle, July 2008

2358 Luca Anderlini, Leonardo Felli and Alessandro Riboni, Statute Law or Case Law?, July 2008

2359 Guglielmo Maria Caporale, Davide Ciferri and Alessandro Girardi, Are the Baltic Countries Ready to Adopt the Euro? A Generalised Purchasing Power Parity Approach, July 2008

2360 Erkki Koskela and Ronnie Schöb, Outsourcing of Unionized Firms and the Impacts of Labour Market Policy Reforms, July 2008

2361 Francisco Alvarez-Cuadrado and Ngo Van Long, A Permanent Income Version of the Relative Income Hypothesis, July 2008

2362 Gabrielle Demange, Robert Fenge and Silke Uebelmesser, Financing Higher Education and Labor Mobility, July 2008 
2363 Alessandra Casarico and Alessandro Sommacal, Labor Income Taxation, Human Capital and Growth: The Role of Child Care, August 2008

2364 Antonis Adam, Manthos D. Delis and Pantelis Kammas, Fiscal Decentralization and Public Sector Efficiency: Evidence from OECD Countries, August 2008

2365 Stefan Voigt, The (Economic) Effects of Lay Participation in Courts - A Cross-Country Analysis, August 2008

2366 Tobias König and Andreas Wagener, (Post-)Materialist Attitudes and the Mix of Capital and Labour Taxation, August 2008

2367 Ximing Wu, Andreas Savvides and Thanasis Stengos, The Global Joint Distribution of Income and Health, August 2008

2368 Alejandro Donado and Klaus Wälde, Trade Unions Go Global!, August 2008

2369 Hans Gersbach and Hans Haller, Exit and Power in General Equilibrium, August 2008

2370 Jan P.A.M. Jacobs and Jan-Egbert Sturm, The Information Content of KOF Indicators on Swiss Current Account Data Revisions, August 2008

2371 Oliver Hülsewig, Johannes Mayr and Timo Wollmershäuser, Forecasting Euro Area Real GDP: Optimal Pooling of Information, August 2008

2372 Tigran Poghosyan and Jakob de Haan, Determinants of Cross-Border Bank Acquisitions in Transition Economies: A Latent Class Analysis, August 2008

2373 David Anthoff and Richard S.J. Tol, On International Equity Weights and National Decision Making on Climate Change, August 2008

2374 Florian Englmaier and Arno Schmöller, Reserve Price Formation in Online Auctions, August 2008

2375 Karl Farmer, Birgit Friedl and Andreas Rainer, Effects of Unilateral Climate Policy on Terms of Trade, Capital Accumulation, and Welfare in a World Economy, August 2008

2376 Monika Bütler, Stefan Staubli and Maria Grazia Zito, The Role of the Annuity’s Value on the Decision (Not) to Annuitize: Evidence from a Large Policy Change, August 2008

2377 Inmaculada Martínez-Zarzoso, The Impact of Urbanization on $\mathrm{CO}_{2}$ Emissions: Evidence from Developing Countries, August 2008

2378 Brian Roberson and Dmitriy Kvasov, The Non-Constant-Sum Colonel Blotto Game, August 2008

2379 Ian Dew-Becker, How Much Sunlight Does it Take to Disinfect a Boardroom? A Short History of Executive Compensation Regulation, August 2008 
2380 Cécile Aubert, Oliver Falck and Stephan Heblich, Subsidizing National Champions: An Evolutionary Perspective, August 2008

2381 Sebastian Buhai, Miguel Portela, Coen Teulings and Aico van Vuuren, Returns to Tenure or Seniority?, August 2008

2382 Erkki Koskela and Jan König, Flexible Outsourcing, Profit Sharing and Equilibrium Unemployment, August 2008

2383 Torberg Falch and Justina AV Fischer, Does a Generous Welfare State Crowd out Student Achievement? Panel Data Evidence from International Student Tests, September 2008

2384 Pedro Gomes and François Pouget, Corporate Tax Competition and the Decline of Public Investment, September 2008

2385 Marko Koethenbuerger, How Do Local Governments Decide on Public Policy in Fiscal Federalism? Tax vs. Expenditure Optimization, September 2008

2386 Ronald McKinnon and Gunther Schnabl, China’s Exchange Rate Impasse and the Weak U.S. Dollar, September 2008

2387 Yan-Leung Cheung, Yin-Wong Cheung and Alan T.K. Wan, A High-Low Model of Daily Stock Price Ranges, September 2008

2388 Louis Eeckhoudt and Harris Schlesinger, Changes in Risk and the Demand for Saving, September 2008

2389 Carsten Hefeker and Blandine Zimmer, Uncertainty and Fiscal Policy in an Asymmetric Monetary Union, September 2008

2390 Jay Pil Choi and Byung-Cheol Kim, Net Neutrality and Investment Incentives, September 2008

2391 Marcel Gérard, Financing Bologna, the Internationally Mobile Students in European Higher Education, September 2008

2392 Annette Alstadsæter and Knut Reidar Wangen, Corporations' Choice of Tax Regime when Transition Costs are Small and Income Shifting Potential is Large, September 2008

2393 António Afonso and Christophe Rault, 3-Step Analysis of Public Finances Sustainability: the Case of the European Union, September 2008

2394 Betsey Stevenson and Justin Wolfers, Economic Growth and Subjective Well-Being: Reassessing the Easterlin Paradox, September 2008

2395 Bernhard Eckwert and Itzhak Zilcha, Private Investment in Higher Education: Comparing Alternative Funding Schemes, September 2008 
2396 Øystein Foros, Hans Jarle Kind and Jan Yngve Sand, Slotting Allowances and Manufacturers’ Retail Sales Effort, September 2008

2397 Mohammad Reza Farzanegan, Illegal Trade in the Iranian Economy: Evidence from a Structural Model, September 2008

2398 Olivier Bos, Charity Auctions for the Happy Few, September 2008

2399 Robert S. Chirinko and Debdulal Mallick, The Marginal Product of Capital: A Persistent International Puzzle, September 2008

2400 Ben D’Exelle and Arno Riedl, Elite Capture, Political Voice and Exclusion from Aid: An Experimental Study, September 2008

2401 Torben M. Andersen and Joydeep Bhattacharya, On Myopia as Rationale for Social Security, September 2008

2402 Fabienne Llense, French CEO Compensations: What is the Cost of a Mandatory Upper Limit?, September 2008

2403 Valentina Bosetti, Carlo Carraro, Alessandra Sgobbi and Massimo Tavoni, Delayed Action and Uncertain Targets. How Much Will Climate Policy Cost?, September 2008

2404 Robert G. Chambers, Rolf Färe, Shawna Grosskopf and Michael Vardanyan, Generalized Quadratic Revenue Functions, September 2008

2405 Leonidas Enrique de la Rosa, Overconfidence in a Career-Concerns Setting, September 2008

2406 Marcus Drometer and Johannes Rincke, The Design of Political Institutions: Electoral Competition and the Choice of Ballot Access Restrictions in the United States, September 2008

2407 Markku Lanne and Helmut Lütkepohl, Stock Prices and Economic Fluctuations: A Markov Switching Structural Vector Autoregressive Analysis, September 2008

2408 Thomas L. Brewer, International Energy Technology Transfers for Climate Change Mitigations, September 2008

2409 Alexander Kemnitz, Native Welfare Losses from High Skilled Immigration, September 2008

2410 Xavier Vives, Strategic Supply Function Competition with Private Information, September 2008

2411 Fabio Padovano and Roberto Ricciuti, The Political Competition-Economic Performance Puzzle: Evidence from the OECD Countries and the Italian Regions, September 2008 